\title{
A Sea of Lilliputians
}

\author{
by \\ Marie-Pierre Aubry \\ Department of Earth and Planetary Sciences \\ Rutgers University \\ 610 Taylor Road, Piscataway, New Jersey 08854-8066 \\ and \\ Department of Geology and Geophysics \\ Woods Hole Oceanographic Institution
}

Woods Hole Ma 02543

Fax: 732445 3374, aubry@rci.rutgers.edu

\begin{abstract}
Smaller size is generally seen as a negative response of organisms to stressful environmental conditions, associated with low diversity and species dominance. The mean size of the coccolithophorids decreased through the Neogene, leading to the prediction that their extant representatives are characterized by poor diversification and low specialization. The study of the (exo)coccospheres of selected taxa in the order Syracosphaerales negates this prediction, revealing that on the contrary some extant lineages are highly diversified and remarkably specialized. Whereas the general role of coccoliths remains indeterminate, this analysis suggests that some highly derived coccoliths may be modified for the collection of food particles, including picoplankton, thus implying that mixotrophy may characterize these lineages. In the extant coccolithophorids, species richness of genera is inversely correlated with the size of cells, definitive evidence that small size is part of a morphologic strategy rather than a sign of evolutionary failure. Because of their extreme minuteness, the extant nannoplankton can be well compared to Lilliputians, but the trend toward size decrease in Neogene lineages is not attributable to the Lilliput effect described by Urbanek (1993).
\end{abstract}


Key words: Extant coccolithophorids, Neogene, size, exococcospheres, functional morphology, mixotrophy.

\section{Introduction}

Cope's law, which in its broadest concept states that the size of organisms increases as lineages diversify, is generally regarded as prevalent among organisms despite a considerable debate as to its significance (e.g., Stanley, 1973, Gould, 1997, Jablonski, 1997, Alroy, 1998, Trammer, 2002). Recently reincarnated as the Cope-Bergmann hypothesis, it predicts that the size of organisms increases in relation to climatic cooling, as verified in Cenozoic deep sea ostracodes (Hunt and Roy, 2006) and Cenozoic planktonic foraminifera (Schmidt et al., 2004, 2006). However there is at least one exception to the Cope-Bergmann hypothesis: Lineages of coccolithophorids (marine Haptophyteae) underwent a general decrease in size during the Neogene cooling (Aubry, 2007).

Size decrease (or dwarfism) through time is generally perceived as a negative phenomenon. The most ubiquitous cases of dwarfism are related to insularity (Case, 1978), emergence of taxonomic groups of high ranks (e.g., appearances of the Classes Reptilia, Mammalia and Aves [Carroll, 1988]), and mass extinction events that affected foremost larger species (well documented for plankton protists at the Cretaceous/Paleogene boundary, e.g., Smit, 1982; Liu and Olsson, 1992; Schmidt et al., 2004). Other less conspicuous cases of dwarfism include the disappearance of the large morphotypes of a lineage prior to the extinction of the smaller ones (evolutionary 'dwarfism' or nanism in mammals in Marshall and Corruccini, 1978), the overall decrease in size prior to extinction of a taxon (pre-extinction dwarfing in Wade and Olsson, this volume), and the reduction in size (dwarfism or stunting) of relict taxa immediately following extinction and prior to re-diversification (Lilliput effect in Urbanek, 1993). Except when insularity is involved, decreases in size have been described as transient phenomena, systematically associated with biologic extinction. 
Due to a poor paleontologic record, only some extant families of coccolithophorids are amenable to documentation of the modalities of their evolutionary history. However, fossil diversity clearly decreased in most families during the late Neogene, in association with the sequential extinction of the large-sized, long-ranging taxa (Aubry, 2007). Extant coccolithophorid communities are both a) characterized by very small size (Aubry, 2007) and b) dominated by the opportunistic species Emiliania huxleyi except in oligotrophic areas (de Vargas et al., 2007). If small size is indicative of stress-inducing ecological conditions acting on multiple lineages (e.g., resource-limited environments, Marshall and Corruccini, 1978) it would be expected that, despite high species richness (Young et al., 2005) extant calcareous nannoplankton are poorly diversified and unspecialized, possibly on the verge of decline (Stanley and Hardie, 1998). There is little resemblance between the robust, thick, large coccoliths of the Paleogene and early Neogene, and the fragile, thin, diminutive coccoliths of the late Pliocene and Pleistocene.

The objective of this paper is to show that despite small size major lineages in the extant calcareous nannoplankton (coccolithophorids) are highly diversified and specialized. This is based on the analysis of the morphology of coccospheres in 5 genera of the order Syracosphaerales. The bulk of the species discussed here are assigned by-default to the genus Syracosphaera and Family Syracosphaeraceae by many authors (e.g., Young et al., 2003), which would suggest a clear lack of differentiation among its 50+ species, and thus fit the prediction of low specialization. However a recent taxonomic revision shows that the genus Syracosphaera s.l. and the Family Syracosphaeraceae s.l. are easily divided into 5 genera and two families (Aubry, in press a; see also Cros, 2000). The implication of this study is that small size in the extant coccolithophorids is part of a morphologic strategy, not the by-product of short-term evolutionary processes associated with extinction. It is hypothesized that the decrease in size in some lineages of the coccolithophorids through the Neogene was associated with a physiological shift towards mixotrophy of the diversifying lineages.

\section{Taxonomic background and methodology}




\subsection{Taxonomic selection}

This study is based on a comparative analysis of the coccospheres secreted by a group of oceanic species assigned to the Families Deutchlandiaceae, Syracosphaeraceae and Umbellosphaeraceae (Aubry, in press; Appendix 1). The first two families account for over 1/3 of species richness among extant coccolithophorids (Young et al., 2005), comprising some 70 formally and informally described species (or morphotypes) that are distributed among 9 genera (Appendix 2). The two species (5 morphotypes) of the Family Umbellosphaeraceae are major components of extant communities in oligotrophic waters (Okada and Honjo, 1973). A characteristic of most species in these three families is the double-layered nature of their coccosphere-a loosely arranged skeleton of individual platelets of calcium carbonate that envelops the unicellular organism. Such coccospheres are dithecate when the two layers are well differentiated, spirothecate when intergradation occurs between layers (Figs. 1-3). Only species with such (dithecate and spirothecate) coccospheres are considered in this study. Three genera of the Family Deutschlandiaceae (Calciopappus, Ophiaster and Michaelsarsia) are usually not regarded as dithecate, but they are critical in this study as their polar apparatus represent extreme cases of polar dithecatism.

\subsection{Exococcoliths as keys to ecological and phylogenetic history}

The endococcospheres in the Families Deutschlandiaceae and Syracosphaeraceae characteristically consist of caneoliths. The exococcosphere in the Family Syracosphaeraceae also consists of caneoliths, but strongly derived, and referred to as umbroliths in the genus Gaarderia (Aubry, in press a). In the Family Deutschlandiaceae, the exococcoliths (cyrtoliths) are of a different type. In the Family Umbellosphaera, the spirotheca is comprised of 'cannaliths' (the endococoliths) and umbelloliths (the exococcoliths), the latter being strongly reminiscent of umbroliths (Appendix 1). This study concerns essentially the exococcoliths, and more particularly their location and arrangement on coccospheres.

In general, exococcoliths have been given little attention, that is particularly true of the taxa discussed here. Yet, a critical question must be asked: Which of the two evolved first in dithecate species: the endo- or the exococcosphere? For the caneolith-bearing species (Families Deutchlandiaceae and Syracosphaeraceae), the stratigraphic record is too scarce to provide a 
reliable answer, even if the oldest known fossil endococcoliths (caneoliths) are much older (late Eocene; Bown et al., 2008) than the oldest known (unquestionable) exococcolith (cyrtoliths; middle Pliocene; Perch-Nielsen, 1980) (Table 1). The evidence is strong that an endococcosphere of caneoliths was first to evolve. Such an endococcosphere is common to all the species here considered, most importantly in those that are monothecate (Appendix 1). If not a primary character, this commonality would require complex explanations, such as unprecedented morphologic convergence, and the loss of a former endococcosphere in the (now) monothecate species. Primary characters tend to be conservative. Caneoliths differ very little among endococcospheres and their (reduced) morphologic diversity is independent of the degree of derivation of the exococcospheres. Thus it is reasonable to conclude that diversification among exococcoliths yield the key not only to phylogenetic reconstruction among taxa, but also to interpreting their ecological adaptation.

\subsection{Extant size and size trends}

Cells in the three dithecate and spirothecate families considered in this paper are biflagellate. Their shape (spherical to strongly elongated) and size ( $2 \mu \mathrm{m}$ to $36 \mu \mathrm{m})$ vary within broad limits; however most are spherical and minute $(50 \%$ are $<10 \mu \mathrm{m})$ (Fig. 4). Coccoliths are always tiny $(0.13 \mu \mathrm{m}$ to $6 \mu \mathrm{m})$, with a mean of $2.5 \mu \mathrm{m}$ (Fig. 5). These sizes are comparable to those of extant taxa with a long geological history whose lineages underwent a pronounced decrease in size during the Neogene (Fig. 6). It is not possible to demonstrate that a similar trend occurred in the families to which the extant taxa examined here belong, but it is reasonable to infer that this is the case.

At least one caneolith-bearing family (?Syracosphaeraceae) had emerged by Late Eocene ( $36 \mathrm{Ma}$; time scale of Berggren et al., 1995) (Table 1). However, there is indirect evidence that the evolution of size in this family has followed the trend towards decreasing size of coccoliths and coccospheres (= proxy for cell size) shown by other extant families (Aubry, 2007). Caneoliths are delicate constructions that do not fossilize well, and although they show a size decrease with age, fossil occurrences are too few to have any significance with regard to size (Table 1). As for the coccospheres, they desintegrate at cell death. A Neogene decrease in size in caneolith-bearing family(ies) is deduced from indirect evidence: 1) The size of coccospheres and coccoliths in caneolith-bearing species fall within the size amplitude of those in other extant 
taxa (figs. 4, 5); 2) the closely related Family Rhabdosphaeraceae underwent a marked size decrease through the Neogene (Fig. 6); and 3) pervasive morphologic convergence between Syracosphaera s.l. species and other phylogenetically unrelated taxa supports an extant strategy towards small size (Aubry, 2007). The earliest, and only, fossil record of the Family Deutschlandiaceae is from the middle Pliocene ( 3.9 Ma; Perch-Nielsen, 1980). These coccoliths are substantially (x3) larger than modern homologues. The earliest record of umbelloliths (Family Umbellosphaeraceae) is early Pliocene. Whereas no systematic study of their size has been conducted, there are strong indications that they too were larger when the lineage was younger (personal observation).

Even though size in the families discussed here has likely followed the trends exhibited by extant taxa with a reliable fossil record, it is not possible to describe how the trend occurred. In other words, this paper does not describe the phenomenon of dwarfing, nor the mechanisms that lead to dwarfism in the coccolithophorids. Instead, it addresses a fundamental question related to it, which is whether small size is necessarily associated with phylogenetic decline in this group. Thus should the inference be incorrect-i.e., size having remained constant in caneolith-bearing lineages since their evolutionary emergence - the conclusions of this paper will remain valid in establishing that extreme diversification and specialization has occurred in long-ranging Neogene lineages despite small size.

\section{Extreme morphologic specialisation of exococcospheres in selected extant lineages}

\subsection{Derived exococcospheres in the Family Deutschlandiaceae}

\subsubsection{Description}

The mutual arrangement and location of cyrtoliths on Deutschlandia-coccospheres unify a number of species with coccoliths and coccospheres of broadly different morphologies. Depending on taxa, they participate in different forms of dithecatism, from complete, to hemispherical, circum, and polar (cf. Fig. 2a-d). The diversity of types encountered differs between two groups of species. In the D. nododa group (Fig. 7) there is no obvious relationship between the type of dithecatism and the morphology of the cyrtoliths, and polar dithecatism does 
not occur. In contrast, coccospheres are morphologically distinct in the D. molischii group (Fig. 8), in which, with one exception (hemispherical dithecatism, cf. Fig. 2c)), dithecatism is polar (cf. Fig. 2d; P1. 1, Figs. 1, 2). Standing on edge and dextrally imbricated (as seen from the antapical pole), the (8 to 10 ) robust and irregularly shaped (contorted) cyrtoliths form a distinct ('simple') corolla centered on the flagellar pole. Typically, and importantly, the outer marginal cycle of each one is truncated at the contact with the preceding cyrtolith, which minimizes overlap between them.

Inserted above the caneoliths at the flagellar (apical) or opposite (antapical) pole (Figs. 3a, c, 9a-c, g-i, 10a-d), the (8 to 10) discoidal-truncated cyrtoliths of Calciopappus and Michaelsarsia occupy the same position on the cell as the contorted cyrtoliths of the D. molischii group (compare fig. 2d and Fig. 10b, d, and P1. 1, figs. 1, 2 and Pl. 2, Fig. 1). Standing on edge and dextrally imbricate (as seen from the antapical pole), they too form a corolla centered on the flagellar pole, with their margin truncated (Figs. 10a-d), which reduces overlap between adjacent cyrtoliths. In Michaelsarsia, three articulated link-cyrtoliths assembled in a row form a long appendage that is fastened to the external side of each discoidal-truncated cyrtolith (P1. 2, Figs. 1-3). The corolla is thus 'compound'. In Calciopappus, an external row of spine-cyrtoliths alternates with the discoidal-truncated cyrtoliths forming an additional corolla (Fig. 10a, b). The corolla is thus 'double'.

Located at the antapical pole the apparatus of Ophiaster cells consists of (6 to 14) appendages, each with 5 to 14 (depending on species) strongly differentiated link-cyrtoliths (Fig. 3b, Fig. 9e, Fig. 10e; Pl. 1, Fig. 5). Each of these is loop-like at both ends, the proximal and distal loops being, respectively, concave and convex in antapical view. The convex loop of a link-cyrtolith fits in, and is articulated with, the concave loop of the next, more distal cyrtolith. The proximal link-cyrtoliths tie all the appendages together, and fasten the apparatus to the cell. Their proximal loops are asymmetrical, broader and more concave than their distal loops. Slightly placed on edge, they imbricate sinistrally as seen in antapical view, holding together the ophiure-like antapical apparatus. They form a 'pseudocorolla'.

\subsubsection{Polar apparatus are derived exococcopshere}


The evidence that the $D$. molischi group is closely related to the archetypical $D$. anthos is unequivocal. As seen from the proximal side, and ignoring general outline, there is greater immediate resemblance between cyrtoliths of the D. molischi group and D. anthos than between cyrtoliths of the latter and the D. nodosa group (Figs. 7, 8). This indicates that the polar, 'unorthodox' exococcosphere (i.e., 'simple corolla') in the D. molischii group is derived from a complete exococcosphere. By extension, the polar apparatus in Calciopappus, Michaelsarsia and Ophiaster are regarded as derived exococcospheres (Fig. 11). They are not only analogous to the corolla of the D. molischii group, they are also homologous to it. These apparatuses are derived from exococcospheres that have undergone profound morphological modifications, including the elongation and differentiation of some cyrtoliths (Figs. 8, 9), and their organization in superstructures (Fig. 10) far more complex than the simple corolla of the D. molischii group. Their corollas and appendages are thus differentiated anatomical features, representing a continuum in degrees of specialization of an exococcosphere (Fig. 11).

The 'double corolla' in Calciopappus and 'compound corolla' in Michaelsarsia include a simple corolla consisting of a single whorl of discoidal-truncated cyrtoliths standing on edge, dextrally imbricate and truncated where they overlap (see above). This single whorl is homologous with the simple corolla of the D. molischii group, the difference being that its cyrtoliths are modified — strengthened. This is particularly true in Michaelsarsia, each discoidaltruncated cyrtolith supporting a spine-cyrtolith (Fig. 9g, Fig. 10c, d; compare Pl. 2, Figs. 1-3 with Pl. 1, Figs. 1, 2).

The least derived exococcosphere is the double corolla of Calciopappus. The long appendages are exterior to the simple corolla, nestled between its cyrtoliths (Fig. 9a-d, Fig.10a, b). The base of each appendage (a fragment of a discoidal-truncated cyrtoliths laterally compressed) supports a remarkably elongated, laterally compressed, cyrtolith. The compound corolla of Michaesarsia, with its appendages directly attached to the simple corolla, is next in complexity (Fig. 9g-k, Fig. 10c, d; Pl. 2, figs.1-3). The shear strength required for support of the arms is made possible by the re-enforcement of each cyrtolith of the simple corolla with numerous superposed proximal laminae (Figs. 9g, h). In Calciopappus, the discoidal-truncated cyrtoliths are strengthened only by two proximal rod-shaped elements spanning the central opening (Fig. 9b, c). The articulated appendages in Michaelsarsia are far more complex than 
those in Calciopappus. The proximal link-cyrtoliths are modified for attachment to the simple corolla; the distal links taper to pointed tips (Fig. 9j, k; Pl. 2, Figs. 2, 3).

The most complex, yet elegantly simple, exococcosphere is that of Ophiaster. The apparatus is comprised solely of appendages, each with three differentiated cyrtoliths. Oriented like the cyrtoliths of a simple corolla and with a shape reminiscent of theirs, the proximal cyrtoliths of all appendages form a pseudocorolla (Fig. 9e, Fig. 10e; Pl. 1, Fig. 5). The complex outline of the link-cyrtoliths, fastened to one another along each appendage by a set of fitting concave and convex loops (much like man-made snap-buttons) testify to the high specialization of the Ophiaster-pseudocorolla.

\subsubsection{Emergence of the pseudocorolla in Ophiaster}

The apical double and compound corollas in Calciopappus and Michaelsarsia are directly comparable to the simple corolla in the D. molischii group. The appendages associated with these corollas are easily explained as resulting from the relocation of specialized cyrtoliths derived from typical circular or elliptical cyrtoliths through bilateral extension.

The emergence of the antapical compound corolla in Ophiaster is unclear at present. A possibility is that it emerged from the evolution of intracytoplasmic antapical spines similar to those found in Calciopappus caudatus. The backward oriented antapical spine of C. caudatus is regarded as similar to the apical spines, and thus corresponds to an extremely stretched out cyrtolith. Several backwards-oriented spines emerging from the cytoplasm at the antapical pole while evolving in shape and arrangement, would form an antapical apparatus. The sinistral imbrication of the proximal cyrtoliths (as seen in antapical view) of the pseudocorolla supports this interpretation (simple corollas have dextral imbrication, see above). Strong similarities between the morphology of their caneoliths and unmineralized periplastic scales already support close phylogenetic relationships between Ophiaster and Calciopappus (Gaarder, 1967; Manton and Oates, 1983). This may imply that, in the detail, the pseudocorolla of Ophiaster is not homologous with the simple corolla of the D. molischii group, Michaelsarsia and Calciopappus, but with the outer corolla of Calciopappus (all cyrtoliths being nevertheless homologous). 
There is little doubt that Michaelsarsia is related to Calciopappus and Ophiaster. However, Manton et al. (1984) pointed out that the latter are closer to one another than to Michaeslsarsia, which is also verified here. The compound corolla of Michaelsarsia arose in a manner similar to that of Calciopappus, and differently from that of Ophiaster. Yet, the appendages of Michaelsarsia are reminiscent of those of the latter, an exemplary case of morphologic convergence.

\subsubsection{Temporal emergence}

The complexity of the exococcospheres discussed here probably implies a long evolutionary history, although it is difficult to estimate the time required to evolve such structurally fine-tuned compound corollas. There are no fossil coccoliths as complex as these to allow, by comparison, an estimate of the time required for reaching such a high degree of specialization, for instance from a common ancestor of Calciopappus and Ophiaster.

\subsection{Spirothecate coccospheres}

Spirothecate coccospheres occur in the monospecific genus Gaarderia (Family Syracosphaeraceae), and the bispecific genus Umbellosphaera (Family Umbellosphaeraceae). Because of structural details common to the coccoliths in these taxa in addition to general morphology, it is likely, although controversial, that they are phylogenetically related (Appendix 1). They are examined here because of the pecularities of their coccosphere, the unusual shape of the external coccoliths (umbroliths and umbelloliths, respectively), and the uncommonly heavy ornamentation in one species.

The inner and outer coccoliths in spirothecas exhibit the same structure, the proportions of the different structural components being reversed (Figs. 12, 13). Whereas the central area is large and the margin is narrow in the inner coccoliths, the former is narrow and the margin is broadly flaring in the outer coccoliths. A continuum occurs from the smallest inner coccoliths with a very narrow margin to the largest outer coccoliths with a very broad margin. Thus, the spherical to oval Gaarderia-coccosphere exhibits a gradation from typical endothecal caneoliths nearest the cell to highly modified external caneoliths (i.e, umbroliths, compare Fig. 12a-c and Fig. 12d-g; see P1. 2, Fig. 4). The spirothecate condition of the subspherical to oblong 
coccosphere of Umbellosphaera species is even more obvious than in Gaarderia, the morphologic continuum being clearer from the innermost coccoliths (cannaliths in contact with the cell) to the most external ones (i.e., umbelloliths, compare Fig. 13a-d and e-h; see P1. 2, Figs. 5, 6; P1. 3, Figs. 1-3).

\section{Adaptive Functional morphology}

The evolution of complex, highly specialized, polar structures from complete exotheca requires an explanation as to their function, as do the unusual spirotheca. The function of coccoliths remains unresolved (Young, 1994; Anning et al., 1996; Paasche, 2002; Browlee and Taylor, 2004). The favored role conferred upon them currently is as armor plating, i.e., physical defense mechanisms against pathogenes and marine grazers (Hamm and Smetacek, 2007). However, the recent demonstration of global forcing on the size and structure of Neogene coccoliths calls into question this interpretation, particularly when smaller size is also associated with mechanically less resistant coccoliths and coccospheres (Aubry, 2007). It seems that a thick, seamless, calcitic crust would protect cells better from predation, or any physical or chemical damage, than a coccosphere of interlocking or imbricate coccoliths that are composed of tiny modified calcitic rhombohedrons fitted together like pieces in a puzzle. The question addressed here, however, is not about the function of coccospheres in general, but the functionality of the highly specialized coccospheres among tiny species. There are no direct observations of living coccolithophorid cells that could shed light on morphological adaptations. Thus, only cautious speculations or educated guesses can be made at this time with regard to function.

\subsection{Exococcospheres as polar apparatus}

The exococcosphere is not always present in all Deutschlandia species, which indicates that their primary role is not of protection against predators.

The morphology of simple corollas allows inwards-outwards movements, similar to the corolla of flowers. Each cyrtolith in simple corollas, whether of Deutschlandia, Calciopappus or Michaelsarsia species, is asymmetrical, being laterally truncated at the contact with the 
preceding cyrtolith (see above). If the corolla consisted of overlapping symmetrical circular or elliptical cyrtoliths, its closure would be very limited. In contrast, minimal overlap of adjacent cyrtoliths positioned at a small angle to the apical/antapical axis of symmetry of the coccosphere (Fig. 10a-d; Pl. 1, Fig. 2; Pl. 2, Fig. 2) ensures flexibility of the corolla, which in turn facilitates opening and closure. This is consistent with published illustrations of apical views of Michaelsarsia and Calciopappus cells, some with fully opened (e.g., Cros and Fortuño, 2002, Fig. 25; Young et al., 2003, pl. 13), others with closed (e.g., Nishida, 1979, Pl. 10) corollas. Presumably, closure is not complete so as to leave a passage for the flagella. If so, the long spine-cyrtoliths of Calciopappus may provide both support and protection for the flagella when cells are at rest. This is consistent with Manton and Oates's observation (1983) that the flagella are shorter than the appendages in Calciopappus. During cell motion the simple corolla would open. Whether closed or half opened, the simple corolla would also provide physical and chemical protection of the bases of the flagella, the haptonema and naked cell membrane at the flagellar pole in Deutschlandia species. This is consistent with the protective role of the cell generally conferred to coccoliths (e.g., Manton, 1986). Young (1994) proposed that the polar apparatus of Calciopappus, Michaelsarsia, and Ophiaster species were likely adaptations for decelerated sinking even though the cells are flagellate. This would not require articulated corollas, unless cells effectuate controlled vertical movements.

An attractive possibility is that the appendages of Calciopappus and Michaelsarsia are involved in food gathering. Little is known of the physiology of their species, but these are larger cells (up to $16 \mu \mathrm{m}$ in length and $13 \mu \mathrm{m}$ in width vs. $6.5-10.5 \mu \mathrm{m}$ ) than those of Deutschlandia species, which may need to supplement their (supposed) autotrophic metabolism by ingestion of food particles. The reports of Calciopappus caudatus being common in subpolar waters (Okada and McIntyre, 1977) and of C. rigidus being more common in nutrient-rich waters (Kleijne, 1993) support hypothetical mixotrophy.

Coccolithophorids are considered to be essentially photoautotrophs ("ocean farmers", de Vargas et al., 2007). However, mixotrophy is widespread among their close non-calcifying relatives (Jones et al., 1994). Pseudopodial formation may be involved in the capture of food particles (Tillmann, 1998), but more generally one of the functions of the haptonema is to gather 
prey (Inouye and Kawachi, 1994). Whereas little is known of the physiology of the coccolithophorids, a complete cycle of phagotrophy-to-disposal of the waste products of digestion have been described for the chromatophores-bearing haploid cells of Coccolithus pelagicus (i.e., Crystallolithus hyalinus Parke and Adams, 1960), and it has been speculated that the diploid cells of this species are seasonally heterotrophic (during spring enrichment of surface waters in nutrients; Paasche, 1968; Okada and Honjo, 1973). Furthermore, the weakly calcified coccolithophorids that inhabit Arctic and Antarctic waters are fully heterotrophic, having no photosynthetic capabilities, either as a primary character, or through secondary loss of the chromatophores (Garrison and Thomsen, 1993; Marchant and Thomsen, 1994).

It is possible that the appendages of Calciopappus and Michaelsarsia compensate for the shortness/?absence of an haptonema (Manton and Oates, 1983, Heimdal and Gaarder, 1981; Manton and Oates, 1983), being essentially food collectors. Slow movements of the appendages, possibly in coordination with movements of the haptonema (when present), would create weak water currents, constituting efficient ways of bringing food particles towards the flagellar opening and haptonema. With their sharp, pointed end, the spine-cyrtoliths of Calciopappus could possibly retain prey. In contrast, the broad, elongated, parallelogram-shaped appendages of Michaelsarsia may serve as "bacterial nets". There is evidence that this might be the case. Manton et al. (1984) were first to document the presence of an unmineralized, reticulate, organic substance in these appendages (P1. 2, Fig. 3). Their preferred interpretation for this was a regulatory function outside the cell. Another proposition is that this organic material contributes to catching tiny bacteria, other picoplankton and food particles, even perhaps to the absorption of nutrients (osmotrophy). This organic 'membrane' may be as sticky as the haptonema is (Inouye and Kachawi, 1994). Protoplasmic movements along the appendages could also move the food particles towards the flagellar opening. A possible function already attributed to some coccoliths and coccospheres is to facilitate osmotrophy (Young, 1994; Siesser, 1998).

Located at the antapical pole, the apparatus of Ophiaster may have a similar function as the corollas discussed above. Its high degree of specialization is attested by the modification of the endococcosphere to fit it, which may be another explanation for the distinctive caneoliths occurring at the antapical pole in several Ophiaster species. These form a low crown in which 
the apparatus is nested (Gaarder, 1967; Manton and Oates, 1983). Particularly interesting is the fact that $O$. reductus, which does not seem to possess an antapical apparatus, bears an antapical row of modified caneoliths as if to hold an antapical apparatus (Manton and Oates, 1983). The apparatus of Ophiaster is highly variable, comprising as few as 5 and as many as 11 appendages. Each appendage consists of between 6 to 14 link-cyrtoliths, which about doubles the total length of the cell (from the tip of the flagella to the tip of the straightened out appendages). It would at first appear inconsistent that the Ophiaster-apparatus is involved in food gathering, the tiny cells of Ophiaster having 2 long achronematic flagella and a coiled haptonema (Gaarder, 1967; Manton and Oates, 1983). However, phagotrophy in Crystallolithus hyalinus occurs at the antapical pole, even though the cells are biflagellate and possess a haptonema (Parke and Adams, 1960). The presence of a feeding apparatus at the antapical pole in Ophiaster would thus be consistent with phagotrophic behavior.

The twisting of the articulated link-cyrtoliths in Ophiaster species allows the appendages to be wrapped around the cell (Fig. 14), forming an exococcosphere. The question is what do these coccospheres represent? One possibility is that the appendages are first organized around the cell as individual cyrtoliths are secreted, being deployed as appendages when a finite number of link-cyrtoliths is reached. The other possibility is that the appendages wrap themselves around the cell when physiological demand arises. Organization of the appendages into a (portable) coccosphere is possibly associated with a feeding mechanism, the food particles caught on the appendages being transferred to the cytoplasm in this fashion. The wrapping (and unwrapping) of the cell by its appendages could be triggered by considerable gyration as described in C. hyalinus (Parke and Adams, 1960). Even more interestingly perhaps are the "balls" of wrapped-around appendages of Ophiaster (P1. 1, Fig. 6). These are not coccospheres: the central cavity provides insufficient room for a cell, and there is no endotheca of caneoliths below the cyrtoliths. Could it be that these "balls" form when the appendages surround a prey or a large food particle?

The closure and opening of the corollas is controlled by the articulated simple corollas. There is a clear relation between the morphology of the cyrtoliths of the simple corolla and the location of the appendages, with an increased amount of strengthening from Deutschlandia to 
Michaelsarsia (see above). Inward-outward movements of the corolla may simply occur by changes in osmotic pressure at the base of the corolla. This would possibly be sufficient for the corolla of Deutschlandia species. When long appendages are also involved, requiring additional strength, specialized structures, perhaps associated with the flagella roots, may occur in the protoplasm. Determination of this fascinating question requires cytologic research. Likewise, the mechanism involved in the movements of each articulated arm poses question. This points again to the extreme specialization of these coccospheres.

\subsection{Spirothecate coccospheres}

Whereas the exococcosphere may or may not be present in several species of Deutschlandia, spirothecate coccospheres are always complete with large exo-, small endo-, and intermediate coccoliths. This supports the functional specificity of the large, highly unusual external coccoliths (umbroliths and umbelloliths). It is unlikely that they shield cells from predation (see above) because these thin coccoliths made of jointed elements are fragile constructions. The thickened ridges that occur in some varieties of Umbellosphaera tenuis may contribute to strengthen the coccoliths, although not necessarily against predation.

The obvious effect of the special morphology of umbroliths and umbelloliths is to double the diameter of the naked cell since only few of them are sufficient to increase 8-fold the volume of the organism. Increased volume generally implies increased buoyancy. However, it is debatable whether improved flotation in Gaarderia and Umbellosphaera is necessary. Cells of other taxa in the same size range and parts of the same plankton community as Gaarderia and Umbellosphaera species, do not carry flotation devices. Yet, the ridges and knobs on the outer coccoliths of Umbellosphaera tenuis may contribute added weight, perhaps leading to some depth stratification on a nannoscale, thus alleviating competition among varieties.

Another interpretation is that umbelloliths and umbroliths are adaptations to provide cells with food particles, acting as food traps. Their funnel-shape would aid collecting organic particles in the narrow central depression. In Gaarderia corolla and Umbellosphaera irregularis (Pl. 2, Figs. 4, 5) the rim is gently sloping towards the central depression. In these two species, the surface of the rim is smooth. In $U$. tenuis the outer periphery of the rim is sloping 
downwards, and the surface of the rim is punctuated by irregularities and/or more or less thickened ridges separated by deep furrows (P1. 2, Fig. 6; P1. 3, Figs. 1-3). This considerably augments the surface of the coccoliths, and increases the chance of retaining particles (picoplankton included). In some varieties ('types') of Umbellosphaera tenuis, the channels are organized in a complex pattern, with narrow, shallower peripheral channels merging into broader radiating channels that open into the central depression (P1. 2, Fig. 6). Presumably this channel patterning is useful in collecting food particles and directing them towards the central depression. Food collection could also be achieved via the sweeping of the flagella (reported in these species by Haldall and Markali, 1955 and Heimdal and Gaarder, 1981) over the food receptacles. A thin protoplasmic film or membrane may cover the surface of the umbroliths and umbelloliths (including the central depression) contributing to the collection and/or absorption of the food particles, though a membrane has not been observed on SEM photographs of Umbellosphaera. However the calcitic elements in the central depression of G. corolla are often covered by a film of organic matter/membrane (P1. 2, Fig. 4) that could be involved in osmotrophy (Brand, 1994) as food particles dissolve on the coccoliths.

It may be possible that some umbelloliths serve as "bacterial farms", although, so far, there is no direct evidence in support of such a hypothesis. The intense superficial ornamentation on the umbelloliths secreted by some varieties of Umbellosphaera tenuis suggests that some coccolithophorids may be adapted to farming, which is known in other planktonic (and benthic) protists. Many planktonic foraminifera, for instance, admit entry of photosynthetic symbionts (in particular dinoflagellates) in their protoplasm, expelling (or destroying) them during gametogenesis (Hemleben et al., 1989). If bacteria is the preferred prey of the haptophytes (haptonema-bearing protists), farming them would provide ecological success. Bacteria (or other picoplantkon) may populate the umbelloliths and live in symbiosis with Umbellosphaera species, providing the latter with basic organic nutrients, vitamins and other necessary components (see review of requirements in Tappan, 1980; Probert and Houdan, 2004). Two picoplanktonic organisms are possible symbionts. One is the cyanobacteria Prochlorococcus $(0.5-0.8 \mu \mathrm{m})$ which proliferates in oligotrophic warms waters (Partensky et al., 1999). The other is a nitrogen-fixing picobacterium that thrives in oceanic oligotrophic waters (Zehr et al., 2005). Symbiosis between some protists and cyanobacteria has long been known (Carpenter, 2002; Pretchl et al., 
2004). Thus, the dominance of Umbellosphaera species in the oligotrophic waters of the midocean gyres (Kleijne et al., 1989; Young, 1994) may be due to bacterial symbiosis, in particular of diazotroph bacteria. This form of aquaculture may resolve the enigma of the extreme adaptation of many extant coccolithophorids to oligotrophic waters (Kilham and Soltau Kilham, 1980). This interpretation of the function of coccoliths requires that the bearers are mixotroph.

\section{Discussion and conclusions}

\subsection{Functional morphology of other strongly derived coccoliths}

This study offers some insights on possible functions of unusual coccoliths known only in extant lineages but probably with a Neogene record extending back to (at least) the Pliocene. This is not to say that all coccoliths in extant lineages are adapted for food collecting; nor is it to say that all tiny extant species are mixotroph, or that only small coccoliths are adapted towards mixotrophy (lopadoliths in Scyphosphaera may as well serve as food collectors). Different coccolith morphostructures probably represent different adaptations regardless of size, in agreement with Young (1994). The hypothesis offered in this paper is that derived coccoliths in several extant lineages are adapted to food harvesting, and that mixotrophy is more widespread than thought among the coccolithoporids. It is noteworthy that whereas the haploid (holocococlith-bearing) cells are more common in oligotrophic waters (e.g., Kleijne, 1993; Triantaphyllou et al., 2002), mixotrophy among the coccolithophorids was first demonstrated in a holococcolith stage (Parke and Adams, 1960).

Other candidates for a trophic function are the trumpet-shaped rhabdoliths of Discosphaera (P1. 3, Fig. 4), a genus of the Family Rhabdosphaeraceae of the Order Syracosphaerales. These are morphologically convergent with umbelloliths (Umbellosphaera) and are equally polymorphic (Kahn and Aubry, 2006). In the trophic perspective presented here, the large size differences between rhadboliths on a single coccosphere would maximize food collection as the cell drifts in the water. Discosphaera tubifera if non-motile, and its exococcosphere may be nothing but a compound food collector. Absorption is possible through direct opening of the central canal of the rhabdolith onto the plasma membrane. 
The idea of coccoliths being food collectors applies as well to a host of other extant taxa, i. al., the tubiform coccoliths of Gladiolithus and Turrilithus (P1. 3, Fig. 5), the pappoliths of Pappomonas and Papposphaera, in addition to numerous cup- or bowl-shaped holococcoliths. Thus there are strong reasons to suspect that derived coccoliths among extant species are specialized for trophic purposes, either for passive collection (non-motile cells) or in a combination of passive and active predation (motile cells). This does not exclude other possible functions of derived coccoliths, such as cell stabilisation, protection of cell membrane, and protection from predation (needle-shaped coccoliths). This may explain endothecal dimorphism in the Families Deutschlandiaceae and Syracosphaeraceae, and monothecal dimorphism in other families (Fig. 1b). In numerous species, the flagellar opening is surrounded by a row of coccoliths similar to others on the coccosphere except for the presence of a central stem (Pl. 1, Fig. 1; P1. 3, Fig. 6), and interpreted as protecting the flagella pole (Young, 1994). This dimorphism may be another aspect of trophic strategy in the coccolithophorids.

\subsection{Perspectives}

Mixotrophy is compatible with the generally small size of the extant nannoplankton. Culture studies have shown that growth rates are higher in smaller coccolithophorids than in larger ones (Ziveri et al., 2003) and there is a general inverse relationship between metabolic rates and size (see Finkel, 2007). However, proof (or disproof) of the participation of coccoliths in the trophic behavior of some species will require either patient microscopic observation, or identification of systematic association of bacteria with them. If the coccoliths in some species are farming grounds, it should be possible to identify the bacteria being farmed via the techniques of molecular biology. The difficulty met in aseptically culturing the vast majority of living species (Probert and Houdan, 2004) may be that growth is not possible in the absence of specific picoplankton. If coccoliths are food receptacles, it will be necessary to determine how the bacteria and other food particles adhere to them; in particular, determination of the nature of the membrane stretched in the center of appendages of Michaelsarsia will be relevant. Is this a dynamic surface comparable to the surface of the haptonema? Does prey catching induce movements of the appendages? A multitude of questions arise (see Inouye and Kawachi, 1994). 
Regardless of whether some coccoliths are morphologically adapted to food collecting, some basic questions need answering regarding the most complex structures known, i.e., the polar appendages of the Family Deutschlandiaceae. Answers to questions such as what controls the movement of the corolla at the flagellar opening, and even more remarkably those of the articulated arms, will necessitate detailed cytologic analysis. The origin and formation of the antapical appendage in Ophiaster can be determined from cytological studies, whereas molecular biology will confirm (or disprove) the ancestral relationships between appendage-bearing and exococcosphere-bearing species and help determine the timing of generic divergence.

\subsection{Size and specialization}

The title of this paper is inspired from The Lilliput effect defined by Urbanek (1993, p. 36) while describing the evolutionary dynamics of biological crises among Silurian graptoloids. The qualifier lilliputians applies well to the extant coccolithophorids, which (for the Cenozoic) rival in small size only their earliest Paleocene counterparts (Aubry, unpublished data). It is important to note, however, that the name does not refer to the effect itself, which is "a remarkable phenomenon of the occurrence of diminutive forms among some of the species in the relic [sic] assemblages". Relict assemblages (Urbanek, 1970) are those that immediately survive a biotic crisis, occurring "prior to any evolutionary response to the new environmental conditions" (Urbanek, 1993, p. 36). The Lilliput effect is often part of a post-event syndrome (Urbanek, 1993) that characterizes some relict assemblages, always including low diversity and species dominance. The extant nannoplankton represent anything but a relict assemblage.

If it was known only from the sedimentary record, the Pliocene to Recent history of the calcareous nannoplankton would be that of a rapid sequential decrease in global diversity through the middle and late Pliocene (Bown et al., 2004; Aubry, 2007), and of considerably impoverished Pleistocene communities with marked species dominance. Pleistocene assemblages would thus be interpreted as relict assemblages sensu Urbanek. Small sizes and fragile construction of many Pleistocene coccoliths have resulted in a significant amount of species being lost during sedimentation and fossilization (Knappertsbusch, 1993; Samtleben et al., 1995; Baumann et al., 2000; Andruleit et al., 2004; Young et al., 2005). 
As a whole the extant nannoplankton is highly diversified, but diversification is uneven at the family and generic level (Fig. 15; see also Figs. 4, 5), species richness in a genus being inversely correlated with cell size of its species. Thus, the long-ranging genera (Coccolithus, Scyphosphaera, Pontosphaera, Helicosphaera) that originated in the Paleogene and possess large cells and coccoliths are little diversified, even though some (Helicosphaera) have experienced Neogene dwarfism. On the contrary, most of the genera with tiny cells and coccoliths (those discussed above, and many other, e.g., Alisphaera, Papposphaera), show high species richness. The combined evidence of 1) an inverse relationship between species richness and cell size and 2) high specialization of the coccoliths among the smallest species confirm that small size is part of an extant morphologic strategy (Aubry, 2007).

In contrast to the Cope-Bergmann hypothesis: different taxa may respond in opposite ways to environmental forcing over the same time interval. In diatoms the surface area of frustules decreases whereas the amplitude of size range increases through the Neogene (Finckel et al., 2005). The maximum size of the planktonic foraminifera also increased during this period (Schmidt et al., 2004). In the coccolithophorids, the large-sized species were lost or dwindled in number during the Neogene, or a rapid decrease in size affected lineages (as in the Reticulofenestra-Gephyrocapsa-Crenalithus-Emiliania complex (Aubry, 2007). This is a longterm dwarfing. In contrast to Cope's law: diversification can be associated with size decreases of organisms (see also Stanley, 1973) as shown by the remarkable morphologic flexibility among extant coccolithophorids.

In conclusion, small size is associated with high degrees of morphologic specialization in extant communities. The size decrease that most lineages have undergone through the Neogene does not point to the demise of the group. On the contrary, many extant taxa are part of wellestablished lineages that were capable of high specialization under environmental forcing. If coccolith morphology in some of these lineages was modified for food harvesting, the overall size decrease that coccolithophorids underwent during the Neogene may have been associated with a progressive physiologic shift from communities comprised of mostly autotrophic species to mostly heterotrophic species, i.e., a (partial) shift "from oceanic farmers to oceanic hunters" (de Vargas et al., 2007). 
Acknowledgements. I am indebted to Bridget Wade for inviting me to contribute this paper to this special issue. I thank her for sharing ideas on the subject of dwarfism. I am grateful to Jack Cook for drafting the figures in this paper, and to Dave Bord for kind assistance in data preparation; to Alicia Kahn, Margarita Dimiza and Maria Triantaphyllou for sharing with me the photographs used in the accompanying plate; to Alicia and Maria, Luc Beaufort, Hui Liu and Colomban de Vargas for discussions on the evolution of the coccolithophorids, and W. A. Berggren and R. K. Olsson for discussions on the evolution and ecology of the planktonic foraminifera. I am particularly grateful to R. K. Olsson, R. Reyment, and two anonymous reviewers for their valuable comments on this paper. I gladly acknowledge Sandra de Cabrera (PDVSA, Puerto La Cruz) for her financial support towards micropaleontologic studies at Rutgers University.

\section{References}

Alroy, J., 1998. Cope's rule and the dynamics of body mass evolution in North American Mammals. Science 280, 731-734.

Andruleit, H., Rogalla, U., Stäger, S., 2004. From living communities to fossil assemblages: origin and fate of coccolithophores in the northern Arabian Sea, inTriantaphyllou, M. (ed.), Advances in the Biology, Ecology, and Taphonomy of Extant Calcareous Nannoplankton, Micropaleontology 50 supplement 1, 5-21.

Anning, T., Nimer, N., Merrett, M. J., and Brownlee, C., 1996. Costs and benefits of calcification in coccolithophorids. Journal of Marine Systems 9, 45-56.

Aubry, M.-P., 1998. Early Paleogene calcareous nannoplankton evolution: A tale of climatic amelioration. In Aubry, M.-P., Lucas, S. and Berggren, W. A., Late Paleocene-Early Eocene Climatic and Biotic Events in the Marine and Terrestrial Records, Columbia University Press, 158-203. 
Aubry, M.-P., 2007. A major mid-Pliocene calcareous nannoplankton turnover: Change in life strategy in the photic zone. In Monechi, S., Rampino, M., and Coccioni, R., "Large Ecosystem Perturbations: Causes and Consequences", Geological Society of America, Special Paper, 25-51.

Aubry, M.-P., in press a. Handbook of Cenozoic Calcareous Nannoplankton. Micropaleontology Press, Vol. 8a.

Aubry, M.-P., in press b. Handbook of Cenozoic Calcareous Nannoplankton. Micropaleontology Press, Vol. 6a.

Baumann, K.-H., Andruleit, H., and Samtleben, C., 2000. Coccolithophores in the Nordic Seas: Comparison of living communities with surface sediment assemblages, Deep-Sea Research II 47, 1743-1772.

Berggren W. A., Kent, D. V., Swisher, C. C., III, and Aubry, M.-P., 1995. A revised Cenozoic geochronology and chronostratigraphy: In Berggren, W. A., Kent, D. V., Aubry, M.-P. and Hardenbol, J., (eds.), Geochronology Time Scales and Global Stratigraphic Correlation, Society of Economic Paleontologists and Mineralogists Special Publication 54, 129-212.

Bown, P. R., 2005. Palaeogene calcareous nannofossils from the Kilwa and Linda areas of coastal Tanzania (Tanzania drilling Project 2003-4). Journal of Nannoplankton Research 27, 21-95.

Bown, P. R., Dunkley Jones, T., Lees, J. A., Randell, R. D., Mizzi, J. A., Pearson, P. N., Coxall, H. K., Young, J. R., Nicolas, C. J., Karega, A., Singano, J., and Wade, B. S., 2008. A Paleogene calcareous microfossil Konservat-Lagerstätte from the Kilwa Group of coastal Tanzania. Geological Society of America Bulletin 120, 3-12.

Brand, 1994. Physiological ecology of marine coccolithophores. in Winter, A., and Siesser, W. G., (Editors), Coccolithophores, Cambridge University Press, 39-49. 
Brownlee, C., and Taylor, A, 2004. Calcification in coccolithophores: A cellular perspective, inThierstein, H.R., and Young, J. (Editors.), Coccolithophores. From Molecular Processes to Global Impact, Springer, Berlin, 31-49.

Carpenter, E. J., 2002. Marine cyanobacterial symbioses, Biology and environment: Proceedings of the Royal Irish Academy 102B1, 15-18.

Carroll, R. L., 1988. Vertebrate Paleontology and Evolution, W.H. Freeman and Co, New York, 1-698.

Case, T., 1978. A general explanation for insular body size trends in terrestrial vertebrates. Ecology 59, 1-18.

Cohen, C. L. D., and Reinhardt, P., 1968. Coccolithophorids from the Pleistocene Caribbean deep-sea core CP-28. Neues Jahrbuch für Geologie und Paläontologie, Abhandlungen 131, 289-304.

Cros, L., 2000. Variety of exothecal coccoliths of Syracosphaera. Journal of Nannoplankton Research 22, 41-51.

Cros, L., and Fortuño, J.-M., 2002. Atlas of Northwestern Mediterranean Coccolithophores. Scientia Marina 66 (suppl. 1), 7-182.

Finkel, Z. V., 2007. Does phytoplankton cell size matter? The evolution of modern marine food webs. In Falkowski, P., and Knoll, A., Evolution of Primary Producers in the Sea, Elsevier, 333-350.

Finkel, Z.V., Katz, M.E., Wright, J.D., Schofield, O., and Falkowski. P.G., 2005, Climaticallydriven macroevolutionary patterns in the cell size of marine diatoms over the Cenozoic, Proceedings of the National Academy of Sciences, USA, 8927-8932. 
Gaarder, K. R., 1967. Observations on the genus Ophiaster Gran (Coccolithineae). Sarsia 29, 183-192.

Gaarder, K. R., Markali, J., and Ramsjfjell, E., 1954. Further observations on the coccolithophorid Calciopappus caudatus. Avhandlinger utgitt av Det Norske VidenskapsAkademi I Oslo, I. Mat.-Naturv. Klasse 1954, 1:3-9.

Gaarder, K. R., and Ramsjfjell, E., 1954. A new coccolithophorid from northern waters, Calciopappus caudatus n. gen. n. sp. Nytt. Mag. Bot. 2, 155-156.

Gaarder, K., and Heimdal, B. R., 1977. A revision of the genus Syracosphaera Lohmann (Coccolithaceae). "Meteor" Forschungsergebnisse Ser. D 24, 54-71.

Garrison, D. L., and Thomsen, H. A., 1993. Ecology and biology of ice biota. Berichte zur Polarforschung 121, 68-74.

Gould, S. J., 1997. Cope’s rule as pyschological artifact. Nature 385, 199-200.

Halldal, P., and Markali, J., 1955. Electron microscope studies on coccolithophorids from the Norwegian Sea, the Gulf Stream and the Mediterranean. Avhandlinger-Norske videnskapsakademi i Oslo. I, Mat.-naturv. Klasse 1, 1-30.

Hamm, C., and Smetacek, V., 2007. Armor: Why, when and how. In Falkowski, P., and Knoll, A., Evolution of Primary Producers in the Sea, Elsevier, 311-332.

Hay, W. W., 1977. Calcareous Nannofossils. In Ramsay, A. T. (ed.), Oceancic, New York: Academic Press 2, 1055-1200. 
Hay, W. W., and Beaudry, F. M., 1973. Calcareous nannofossils-Leg 15, Deep Sea Drilling Project. In: Edgar, N. T., Saunders, J. B., et al., Initial Reports of the Deep Sea Drilling Project. Washington, D. C.: U.S. Government Printing Office 15, 625-683.

Hay, W. W., Mohler, H. P., Roth, P. H., Schmidt, R. R., and Boudreaux, J. E., 1967. Calcareous nannoplankton zonation of the Cenozoic of the Gulf Coast and Caribbean-Antillean area, and transoceanic correlation. Transactions of the Gulf Coast Association of Geological Societies $17,428-480$.

Heimdal, B. R., 1993. Modern Coccolithophorids. In Thomas, C. R., Marine Phytoplankton, A Guide to Naked Flagellates and Coccolithophorids, Academic Press, 147-247.

Heimdal, B. R., and Gaarder, K. R., 1981. Coccolithophorids from the northern part of the eastern central Atlantic. II. Heterococcolithophorids. "Meteor" Forschungsergebnisse Ser. D 33, 37-69.

Hemleben, C., Spindler, M., and Roger Anderson, O., 1989. Modern Planktonic Foraminifera, Springler-Verlag, 1-363.

Hunt, G., and Roy, K., 2006. Climate change, body size evolution, and Cope's rule in deep sea ostracods. Proceedings of the National Academy of Sciences 103, 1347-1352.

Inouye, I., and Kawachi, M., 1994. The haptonema. In Green, J. C., and Leadbeater, B. S. C., The Haptophyte Algae, Systematic Association Special 51 Oxford: Clarendon Press, 73-89.

Inouye, I., and Pienaar, R. N., 1988. Light and electron microscope observations of the type species of Syracosphaera, S. pulchra (Prymnesiophyceae), British Phycological Journal 23, 205-217.

Jablonski, D., 1997. Body size evolution in Cretaceous molluscs and the status of Cope's rule. Nature 385, 250-252. 
Jones, H. L. J., Leadbeater, B. S. C., and Green, J. C., 1994. Mixotrophy in haptophytes. In Green, J. C., and Leadbeater, B. S. C., The Haptophyte Algae, Systematic Association Special Volume 51, Oxford: Clarendon Press, 247-263.

Kaenel, E. de, and Villa, G., 1996. Oligocene-Miocene calcareous nannofossil biostratigraphy and paleoecology from the Iberia Abyssal Plain. In: Whitmarsh R. B., Sawyer D. S., Klaus A., and Masson, D. G. (Eds.), Proceedings of the Ocean Drilling Program, Scientific Results. College Station, Texas: Ocean Drilling Program 149, 79-145.

Kahn, A., and Aubry, M.-P., 2006. Intraspecific morphologic variability in the Family Rhabdosphaeraceae, Micropaleontology 52, 317-342.

Kamptner, E., 1928. Über das System und die Phylogenie der Kalkflagellaten. Archiv für Protistenkunde 64, 19-43.

Kleijne, A., 1993. Morphology, Taxonomy and Distribution of Extant Coccolithophorids (Calcareous Nannoplankton). Enschede, The Netherlands: FEBO, 169-226.

Kleijne, A., Kroon, D., and Zeveboom, W., 1989. Phytoplankton and foraminiferal frequencies in northern Indian Ocean abd Red Sea surface waters. Netherlands Journal of Sea Research 24, 531-539.

Kilham, P. and Soltau Kilham, S., 1980. The evolutionary ecology of phytoplankton. In Morris, I., (ed.), The Pysiological Ecology of Phytoplankton, Studies in Ecology 7, 493-570.

Knappertsbusch, M., 1993. Geographic distribution of living and Holocene coccolithophores in the Mediterranean Sea. Marine Micropaleontology 21, 219-247. 
Lemmerman, E., 1903. Das Phytoplankton des Meeres. II. Beitrag. Abh. Naturw. Ver. Bremen $17,341-418$.

Liu, C., and Olsson, R. C., 1992. Evolutionary adaptative radiation of microperforate planktonic foraminifera follwing the K/T Mass extinction event. Journal of Foraminiferal Research 22, 328-346.

Lohmann, H., 1902. Die Coccolithophoridae, eine Monographie der Coccolithen bildenden Flagellaten, zugleich ein Beitrag zur Kenntnis des Mittelmeerauftriebs. Archiv für Protistenkunde 1, 89-165.

Lohmann, H., 1903. Neue Untersunchungen über den Reichthum des Meeres an Plankton und über die Brauchbarkeit der verschiedenen Fangmethoden. Zugleich auch ein Beitrag zur Kenntniss des Mittelmeerauftriebs. Wiss. Meeresuntersuch . Kiel 7, 1-87.

Lohmann, H., 1912. Untersunchungen über das Pflanzen- und Tierleben der Hochsee. Zugleich ein Bericht über die biologischen Arbeiten auf der Fahrt der "Deutschland" von Bremerhaven nach Buenos aires in der Zeit vom 7. Mai bis 7. September 1911. Veröff. Inst. Meeresk. Univ. Berlin, N.F., Geogr.-Naturw. Reihe 1, viii + 1-92.

Lohmann, H., 1913. Über Coccolithophoriden. Verh. Deutsch. Zool. Ges. 23, 143-164.

Manton, I., 1986. Functional parallels between calcified and uncalcified periplasts. In Leadbeater, B. S. C., and Riding, R., (Eds.), Biomineralization in Lower Plants and Animals, Systematic Association Special volume 30, 157-172.

Manton, I., and Oates, K., 1983. Nanoplankton from the Galapagos Islands: Two genera of spectacular coccolithophorids (Ophiaster and Calciopappus), with special emphasis on unmineralized periplast components. Philosophical Transactions of the Royal Society London, (B) 300, 435-462. 
Manton, I., Bremer, G., and Oates, K., 1984. Nanoplankton from the Galapagos Islands: Michalesarsia elegans Gran and Halopappus adriaticus Schiller (coccolithophorids) with special reference to coccoliths and their unmineralized components. Philosophical Transactions of the Royal Society London (B) 305, 183-199.

Marchant, H. J., and Thomsen, H. A., 1994. Haptophytes in polar waters. In Green, J. C., and Leadbeater, B. S. C., The Haptophyte Algae, Systematic Association Special Volume 51, Oxford: Clarendon Press, 209-228.

Marshall, L. G., and Corruccini, R. S., 1978. Variability, Evolutionary rates and allometry in dwarfing lineages. Paleobiology 4, 101-119.

Martini, E., and Müller, C., 1972. Nannoplankton aus dem nördlichen Arabischen Meer. "Meteor" Forschungsergebnisse ser. C 10, 63-74.

Müller, C., 1974. Nannoplankton aus dem Mittel-Miozän von Walbersdorf (Burgenland). Senckenbergiana Lethaea 55, 389-405.

Nishida, S., 1979. Atlas of Pacific nannoplanktons. News of Osaka Micropaleontologists. Special Paper 3, 1-31.

Okada, H., 1990. Quaternary and Paleogene calcareous nannofossils, Leg 115. In: Duncan, R. A., Backman, J., Peterson, L. C., et al., Proceedings of the Ocean Drilling Program, Scientific Results. College Station, Texas: Ocean Drilling Program 115, 129-174.

Okada, H., and Honjo, S., 1973. The distribution of oceanic coccolithophorids in the Pacific. Deep-Sea Research 20, 355-374.

Okada, H., and McIntyre, A., 1977. Modern coccolithophores of the Pacific and North Atlantic Oceans. Micropaleontology 23, 1-55. 
Paasche, E., 1968. Biology and physiology of coccolithophorids. Annual Review of Microbiology 22, 71-86.

Paasche, E., 2002. A review of the coccolithophorid Emiliania huxleyi (Prymnesiophyceae) with particular reference to growth, coccolith formation, and calcification-photosynthesis interactions. Phycologia 40, 503-529.

Parke, M., and Adams, I., 1960. The motile (Crystallolithus hyalinus Gaarder \& Markali) and non-motile phases in the life history of Coccolithus pelagicus (Wallich) Schiller. Journal of the Marine Biological Association of the United.Kingdom 39, 263-274.

Partensky, F., Hess, W. R., and Vaulot, D., 1999. Prochlorococcus, a marine photosynthetic prokaryote of global significance. Microbiology and Molecular Biology Reviews, Mar. 1999, 106-127.

Perch-Nielsen, K., 1980. New Tertiary calcareous nannofossils from the South Atlantic. Eclogae geologicae Helvetiae 73, 1-7.

Pretchl, J., Kneip, C., Lockhart, P., Wenderoth, K., and Maier, U.-G., 2004. Molecular Biology and Evolution 21, 1477-1481.

Probert, I., and Houdan, A., 2004. The laboratory culture of coccolithophores. In Thierstein, H. R., and Young, J. R. (eds.), Coccolithophores-from Molecular Processes to Global Impact, Springer, 217-249.

Samtleben, C., Schäfer, P., Andruleit, H., Baumann, A., Buamann, K.-H., Kohly, A., Matthiessen, J., and Schröder-Ritzrau, A., 1995, Plankton in the Norwegian-Greenland Sea: from living communities to sediement assemblages - an actualistic approach, Geologische Rundschau, 84, 108-136. 
Schmidt, D.N, Thierstein, H.R., Bollmann, J., and Schiebel, R., 2004, Abiotic forcing of plankton evolution in the Cenozoic, Science 303, 207-210.

Schmidt, D., Lazarus, D., Young, J. R., and Kucera, M., 2006. Biogeography and evolution of body size in marine plankton. Earth-Sciences review 78, 239-266.

Siesser, W. W., 1998. Calcareous nannofossil Genus Scyphosphaera: structure, taxonomy, biostratigraphy and phylogeny. Micropaleontology 44, 351-384.

Smit, J., 1982. Extinction and evolution of planktonic foraminifera after a major impact at the Cretaceous/Tertiary boundary. Geological Soceity of America Special Publication 190, 329-352.

Stanley, S. M., 1973. An explanation for Cope’s rule. Evolution 27, 1-26

Stanley, S.M., and Hardie, L.A., 1998, Secular oscillations in the carbon mineralogy of reefbuilding and sediment-producing organisms driven by tectonically forced shifts in seawater chemistry, Palaeogeography, Palaeoclimaology, Palaeoecology 144, 3-19.

Stradner, H., 1973. Catalogue of calcareous nannoplankton from sediments of Neogene Age in the eastern North Atlantic and Mediterranean Sea. In: Ryan, W. B. F., Hsü, K. J., et al., Initial Reports of the Deep Sea Drilling Project. Washington, D. C.: U.S. Government Printing Office 13, 1137-1199.

Stradner, H., and Fuchs, R., 1978. Das Nannoplankton in Österreich. In: Papp, A., et al. (Eds.), Chronostratigraphie und Neostratotypen, Band VI: Miozän $M_{4}$ Badenian (Moravien, Wielicien, Kosovien). Bratislava: VEDA, 489-531.

Tappan, H., 1980. The Paleobiology of Plant Protists. San Francisco: W. H. Freeman and Co., $1-1028$. 
Tillmann, U., 1998. Phagotrophy by a plastidic haptophyte, Prymnesium patelliferum. Aquatic Microbial Ecology 14, 155-160.

Theodoridis, S., 1984. Calcareous nannofossil biozonation of the Miocene and revision of the helicoliths and discoasters. Utrecht Micropaleontological Bulletins 32, 1-271.

Trammer, J., 2002. Power formula for Cope's rule. Evolutionary Ecology Research 4, 147-153.

Triantaphyllou, M. V., Dermitzakis, M. D., and Dimiza, M. D., 2002. Holo- and heterococcolithophorids (calcareous nannoplankton) in the Gulf of Korthi (Andros Island, Aegean Sea, Greece) during late summer 2001. Revue de Paléobiologie 21, 353-369.

Urbanek, A., 1970. Neocucullograptinae n. subfam. (Graptolithina) - their evolutionary and stratigraphic bearing. Acta Palaeontologica Polonica, Warsazawa 15, 163-388

Urbanek, A., 1993. Biotic crises in the istory of upper Silurian graptoloids: a palaeobiological model. Historical Biology 7, 29-50.

Vargas, C., de, Aubry, M.-P., Probert, Y., and Young, J., 2007. Origin and evolution of Coccolithophores: A paleonto-genomic approach. In Falkowski, P., and Knoll, A., Evolution of Primary Producers in the Sea, Elsevier, 251-285.

Winter, A., and Siesser, W. G., 1994. Atlas of living coccolithophores. In: Winter, A., and Siesser, W. G. (Eds.), Coccolithophores. Cambridge: Cambridge University Press, 107159.

Young, J., 1994, Function of coccoliths, in Winter, A., and Siesser, W. G., (Editors), Coccolithophores, Cambridge University Press, 63-82. 
Young, J., Geisen, M., Cros, L., Kleijne, A., Sprengel, C., Probert, I., and Østergaard, J., 2003, A guide to extant coccolithophore taxonomy, Journal of Nannoplankton Research Special Issue $1,1-125$.

Young, J. R., Geisen, M., and Probert, I., 2004. Structure and morphogenesis of the cococliths of the CODENET species. In Thierstein, H. R., and Young, J. R. (eds.), Coccolithophoresfrom Molecular Processes to Global Impact, Springer, 191-216.

Young, J. R., Geisen, M., and Probert, I., 2005, A review of selected aspects of coccolithophore biology with implications for paleobiodiversity estimation. Micropaleontology 51 supplement 1, 267-288.

Zehr, J. P., Methe, B., and Foster, R., 2005. New nitrogen-fixing microorganisms from the oceans: Biological aspects and global implications. In Y.-P. Wang, Lin, M., Tian, z.-X., Elmerich, C., Newton, W. E. (eds.) Biological Nitrogen Fixation, Sustainable Agriculture and the Environment. Proceedings of the $14^{\text {th }}$ International Nitrogen Fixation Congress. Current Plant Science and Biotechnology in Agriculture, 361-365.

Ziveri, P., Stoll, H., Probert, I., Klaas, C., Geisen, M., Ganssen, G., Young, J., 2003, Stable isotope 'vital effects' in coccolith calcite, Earth and Planetary Science Letters 210, 137-149. 


\section{Figure Captions}

Fig. 1. Sketches of monothecate coccospheres. Monothecate coccospheres consist of a single envelope of coccoliths. All coccoliths may be identical: the coccosphere is monomorphic (a). Coccoliths of two types may occur: the coccosphere is dimorphic (b). Coccoliths may show gradation in size from the apical (flagellar) pole to the antapical pole: the coccosphere is varimorphic (c).

\section{Monothecate coccospheres}

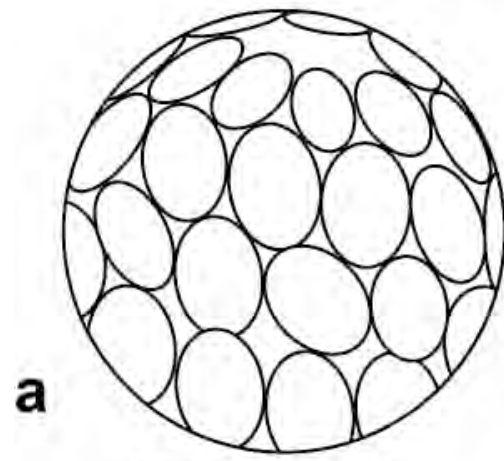

Monomorphic

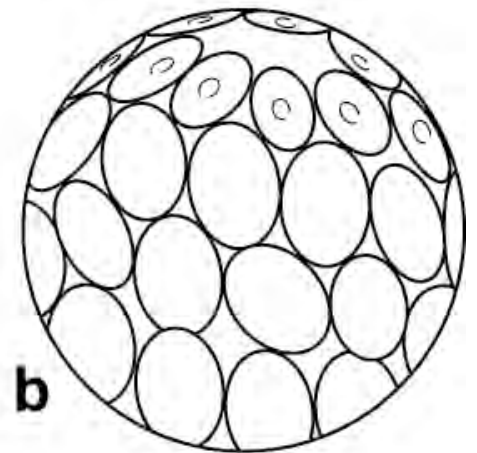

Dimorphic
C

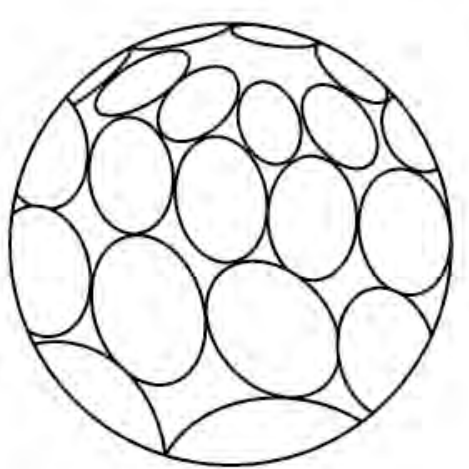

Varimorphic 
Fig. 2. Sketches of dithecate coccospheres. Dithecate coccospheres are double-layered. The layer (endococcosphere) immediately surrounding the cell is comprised of coccoliths (endococcoliths) that markedly differ from those (exococcoliths) of the outer layer (exococcosphere). Whereas the endococcoliths always form a continuous envelope, the exococcoliths may also be restricted to part of the cell, either forming a transverse row (b), covering one hemisphere (c), or surrounding a pole (d). The arrangement of the cyrtoliths varies among Deutschlandia species. In several species of the D. nodosa group (Fig. 7), as in D. anthos (archetype), cyrtoliths strongly overlap, forming a continuous envelope (a) around the endococcosphere, which is interrupted only at the flagellar pole. In other species of the latter group, the cyrtoliths overlap slightly and surround the endococcosphere in a single row (b). In the D. molischii group (Fig. 8) dithecatism is polar (with one exception).

\section{Dithecate coccospheres}
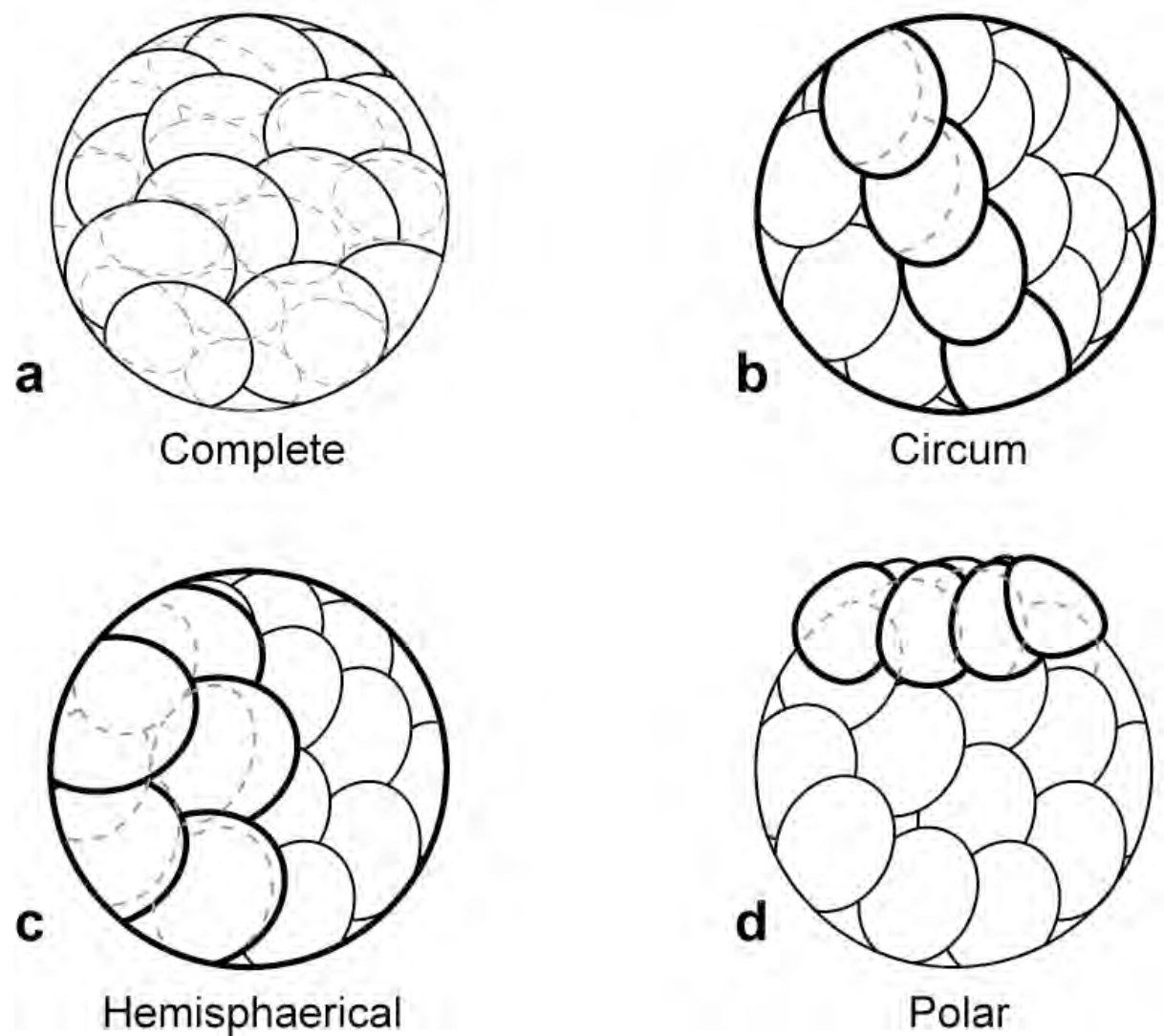

Hemisphaerical 
Fig. 3. Line drawings of coccospheres of species of Calciopappus (a), Ophiaster (b) and Michaelsarsia (c) (Family Deustchlandiaceae); of Syracosphaera s.st. (d) (Family Syracosphaeraceae); and of Umbellosphaera (e) (Family Umbellosphaeraceae). (modified after Heimdal, 1993). (a) to (c) are examples of polar dithecatism. (d) is an example of complete dithecatism. (e) is an example of spirothecatism. Exococcoliths in distal (above) and side (below) views are shown next to the coccosphere of S. pulchra (d). Cannaliths (above) and umbelloliths (below) are shown next to the coccosphere of $U$. irregularis(e). All taxa shown here possess flagella, but these are shown only in Ophiaster.

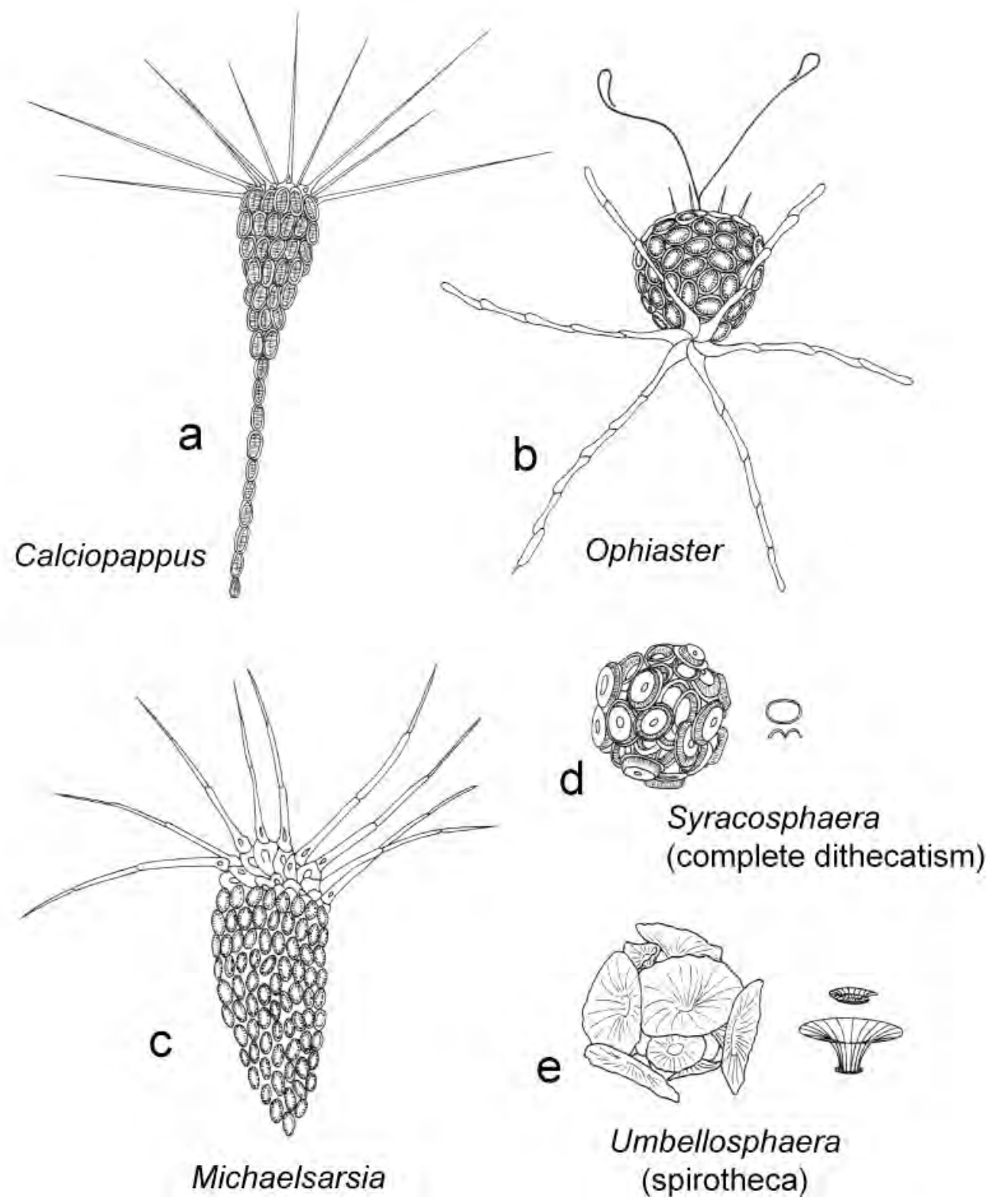


Fig. 4. Comparison of sizes [diameter when (sub)spherical; length when elliptical or fusiform] of the coccospheres secreted by the extant coccolithophorids. In the cases of tall coccoliths, size is that of exococcosphere (see Kahn and Aubry, 2006). A: Species of the Families Deutchlandiaceae and Syracosphaeraceae; B: Species of the Families Calciosoleniaceae, Rhabdosphaeraceae, and incertae sedis; see young et al., 2003 for taxonomy at the family level); C: placolith-bearing species (Families Coccolithaceae, Calcidiscaceae, Noelarhabdaceae). Data source from Aubry (in press, and references therein). Differences in size related to taxonomic groups are discussed in Aubry (2007). 

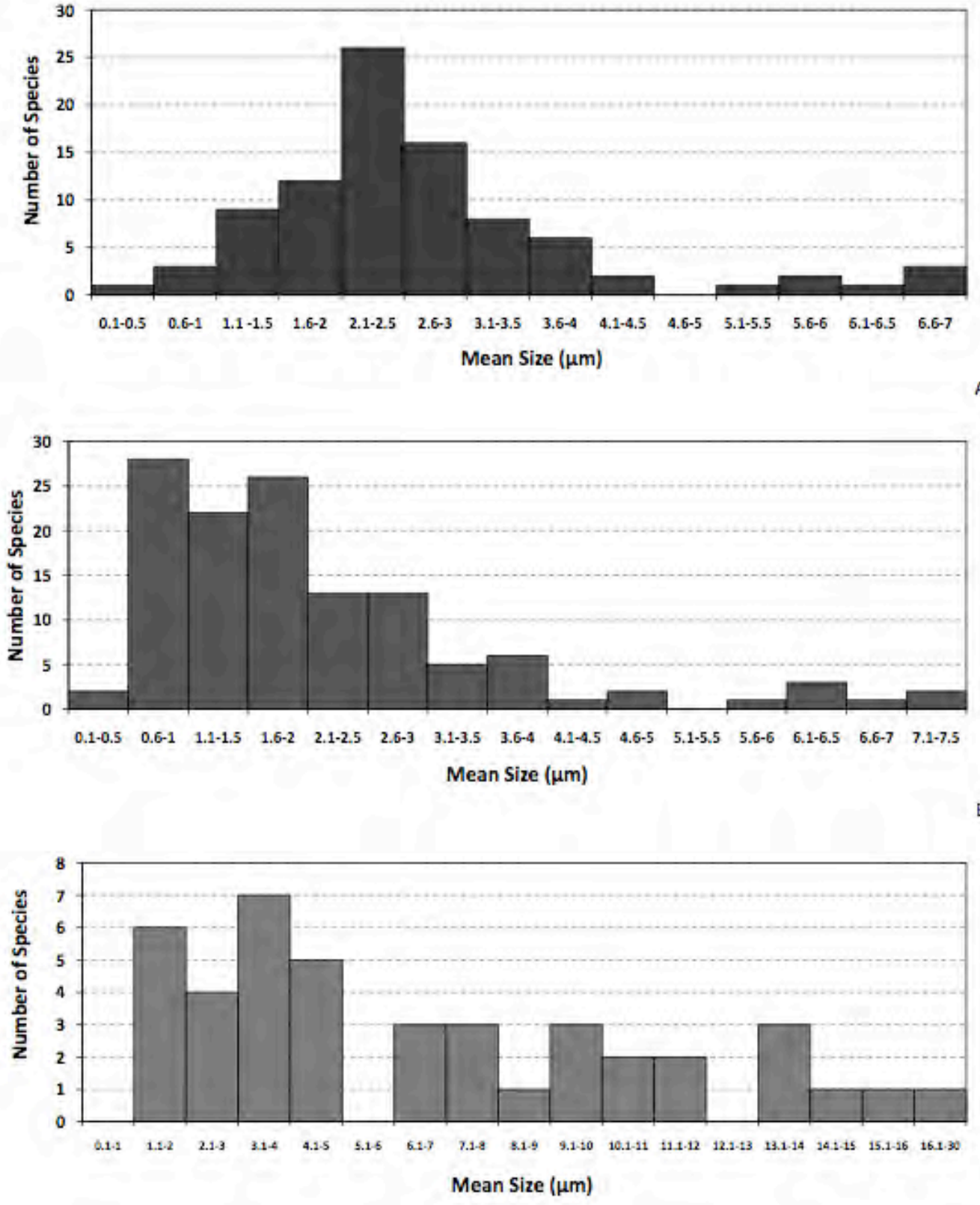
Fig. 5. Comparison of sizes of the coccoliths secreted by the extant coccolithophorids. A to C, and data source as in Fig. 4.
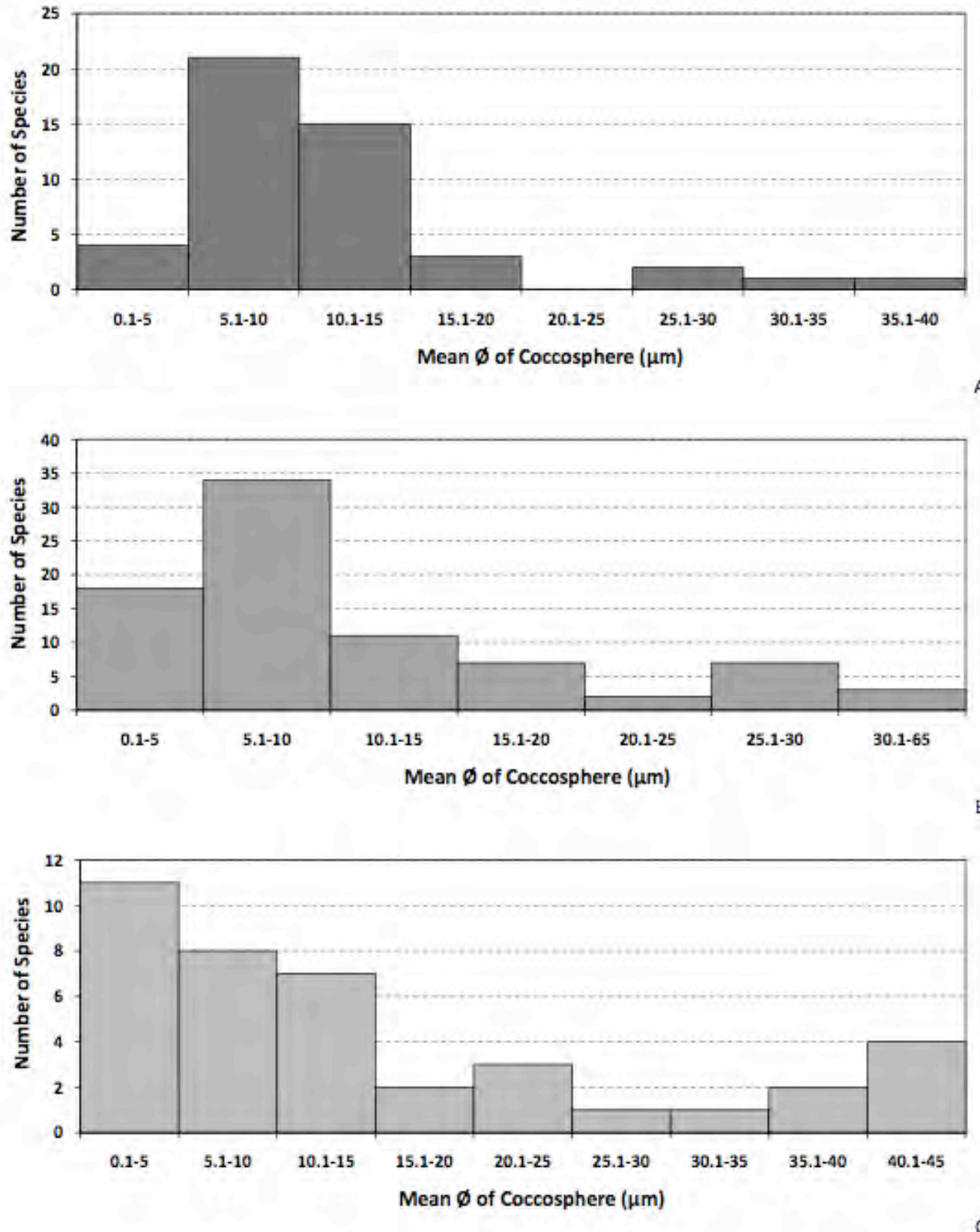
Fig. 6. Decrease in size of the coccoliths of the Family Rhabdospheraceae through the Neogene (After Aubry, 2007, Fig. 5A). This family is closely related to the Families Syracosphaceae and Deutschlandiaceae (with a poor fossil record), and the same trend towards decreasing size may have occurred in the three families.

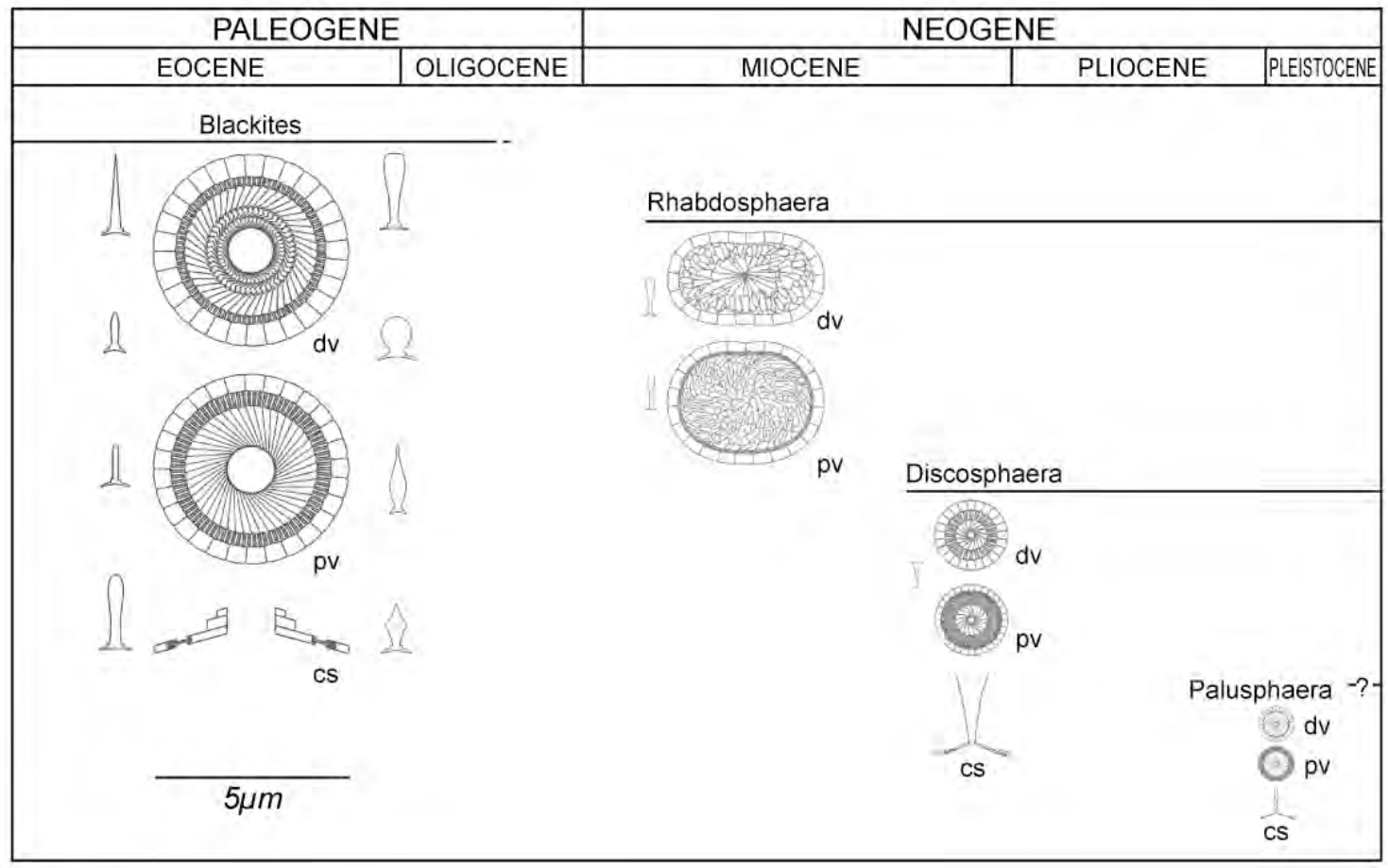


Fig. 7. Morphostructure of the cyrtoliths of the Deutschlandia nodosa group. In this group, the three cycles are easily delineated because the sutures between elements are always distinct. The outer marginal cycle occupies $<1 / 3$ of the diameter of the cyrtolith; the inner marginal cycle generally consists of rod-shaped elements that show all developmental intermediates between prominent and elongated (as in D. nodosa) to subdued and very short (as in Deutschlandia type L). The central area consists of one cycle of little or strongly imbricate elements, except in Deutschlandia sp. type J where superposed cycles of elements give a stratified appearance to the distal side of the cyrtolith. Other departures from the basic plan in this group include a distal bending with slight overlap of portion of the margin (in $D$. delicata) or its asymmetrical, pseudospiral development (in Deutschlandia sp. type K). The cyrtolith of $D$. anthos represents the archetype from which all other morphostructures of the $D$. nodosa group evolved. Although morphologic diversity is large in this group, there are little fundamental departures from the archetype, the largest differences being stratified cyrtoliths and circum-dithecatism (cf. Fig. 2). 


\section{Deutschlandia nodosa Group}

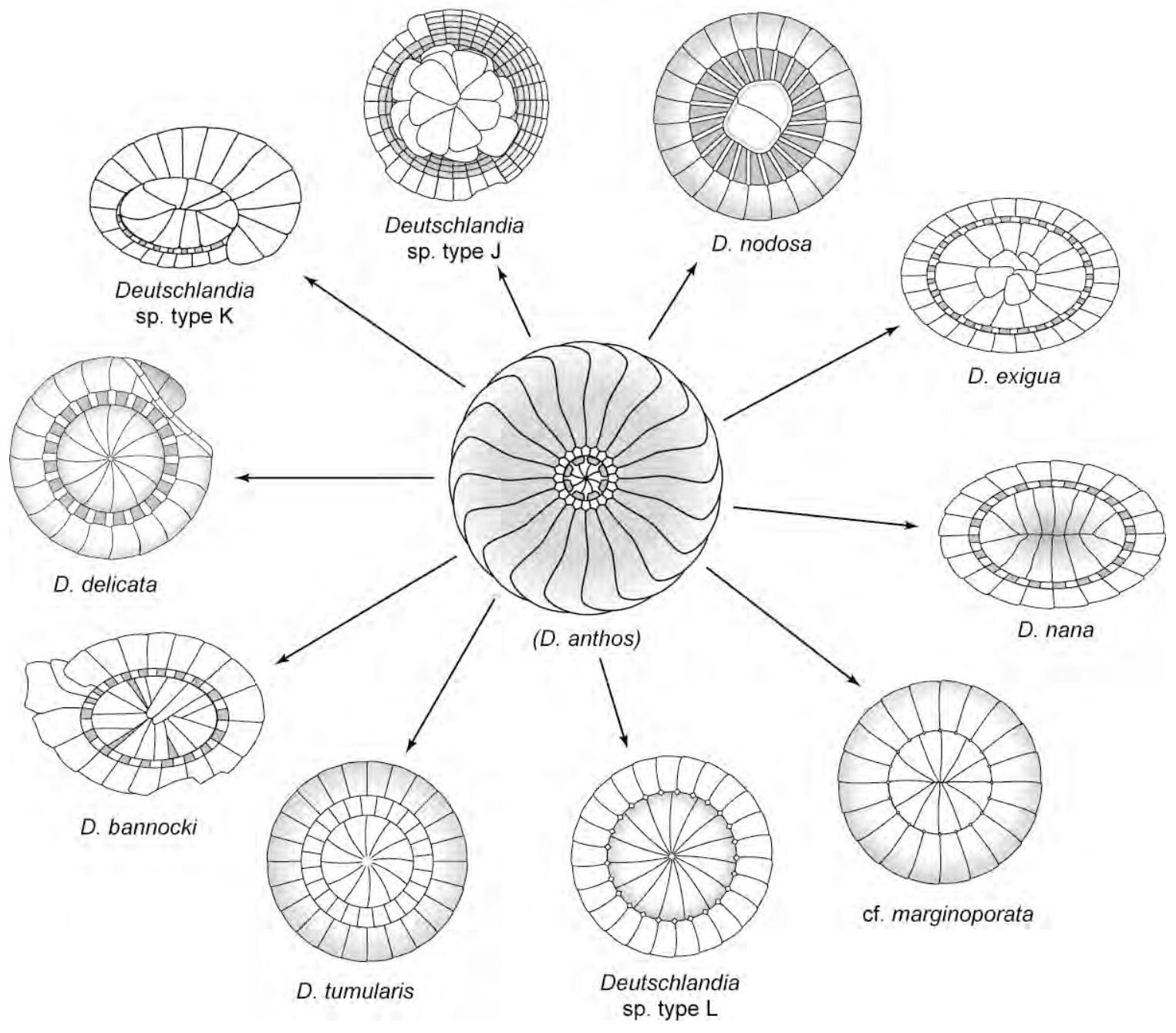


Fig. 8. Morphostructure of the cyrtoliths of the Deutschlandia molischii group. In this group, cycles and sutures are difficult to distinguish in SEM photographs because of dense calcification. However they are clearly visible in TEM photographs (Heimdal and Gaarder, 1981). The outer marginal cycle is broad, consisting of jointive petaloid elements, and markedly truncated in most species (and this to the extreme in Deutschlandia sp. II cf. $D$. epigrosa). The inner marginal cycle is narrow and consists of jointive quadrangular elements. The central cycle forms a conical protrusion which is pointing distally in $D$. marginoporata (as in D. anthos), proximally in the other species. This cycle is formed of broadly radiating elements that abut part of the inner marginal cycle, leaving two characteristic, opposite and symmetrical crescent-shaped openings in the central area. The cyrtolith of $D$. anthos represents the archetype from which all other morphostructures of the D. molischii group evolved as well as the cyrtoliths that form the articulated appendages characteristic of species of Calciopappus, Ophiaster, and Michaelsarsia. The D. molischi group thus exhibits major departures from the archetype. 


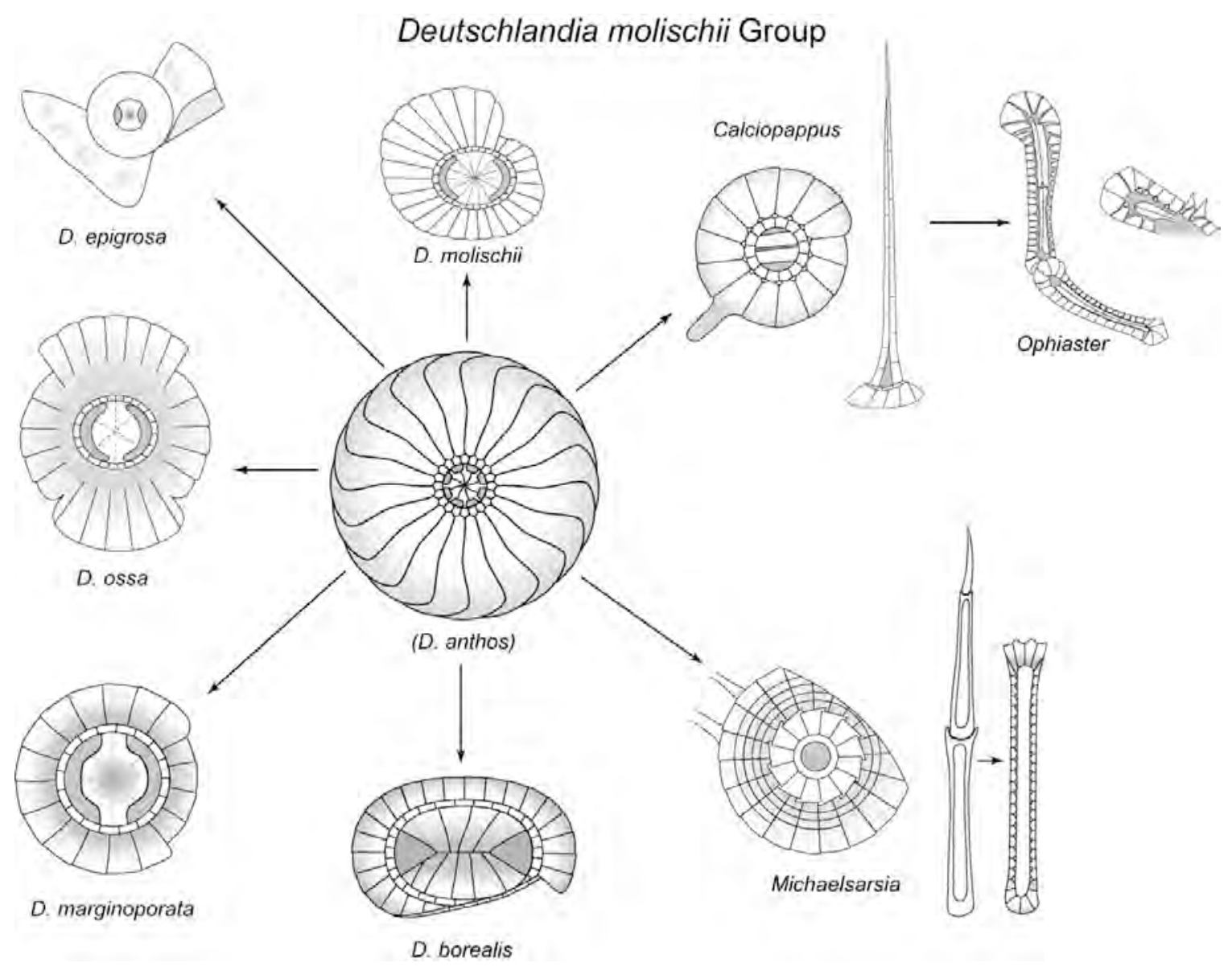


Fig. 9. Morphostructure of the cyrtoliths forming the polar appendages in Calciopappus, Ophiaster and Michaelsarsia. a-c, g-i: Discoidal-truncated cyrtoliths; d: Spine-cyrtolith; e, f, j, k: Link-cyrtolith. a, g: distal views; c, e, i: proximal view; b, h: cross section. In g, area of attachment of link-cyrtolith to distal side of discoidal-truncated cyrtolith shown in dash lines.

The apparatus of Ophiaster is composed solely of link-cyrtoliths (e, f); that of Calciopappus is comprised of discoidal-truncated (a-c) and spine-cyrtoliths (d); and that of Michaelsaria consists of discoidal-truncated (g-i) and link- (j, k) cyrtoliths. The structural similarity between the link- and spine-cyrtoliths on the one hand, and the Deutschlandiacyrtoliths on the other, is readily established (Aubry, in press; fig. 8), the former resulting from the conjunct lateral compression and polar extension of a discoidal cyrtolith. The structure of the discoidal-truncated cyrtoliths (see also Pl. 2, Fig. 3) is more difficult to establish because of their thickness. In these subcircular, broadly elliptical coccoliths that are truncated on one side at the contact with overlapping coccoliths, the inner marginal cycle is mostly visible in TEM photographs. In contrast, the other two cycles are prominent. The convex, distal side consists of a broad gently sloping cyle of $\sim 20$ slightly imbricated elements that surrounds a double inner cycle of narrow elements $(\mathrm{a}, \mathrm{g})$. The concave, proximal side consists (in Michaelsarsia [i]) of several superposed laminae of quadrangular elements, orderly arranged so that their diameter decreases progressively outwards. 

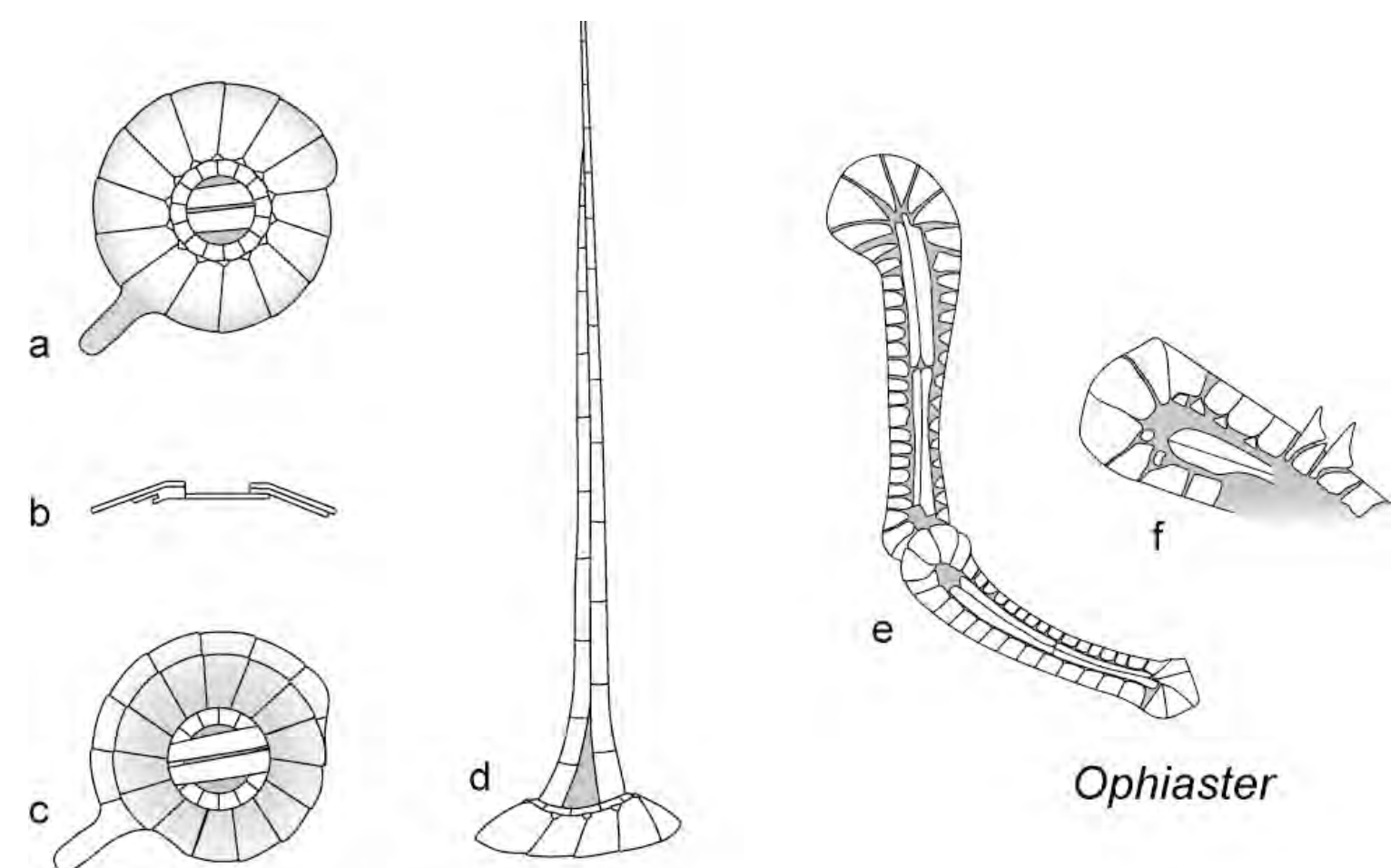

c

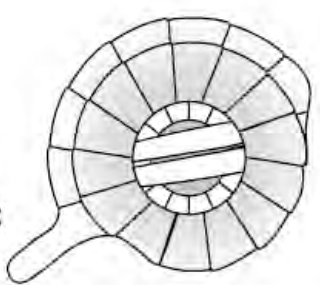

Calciopappus
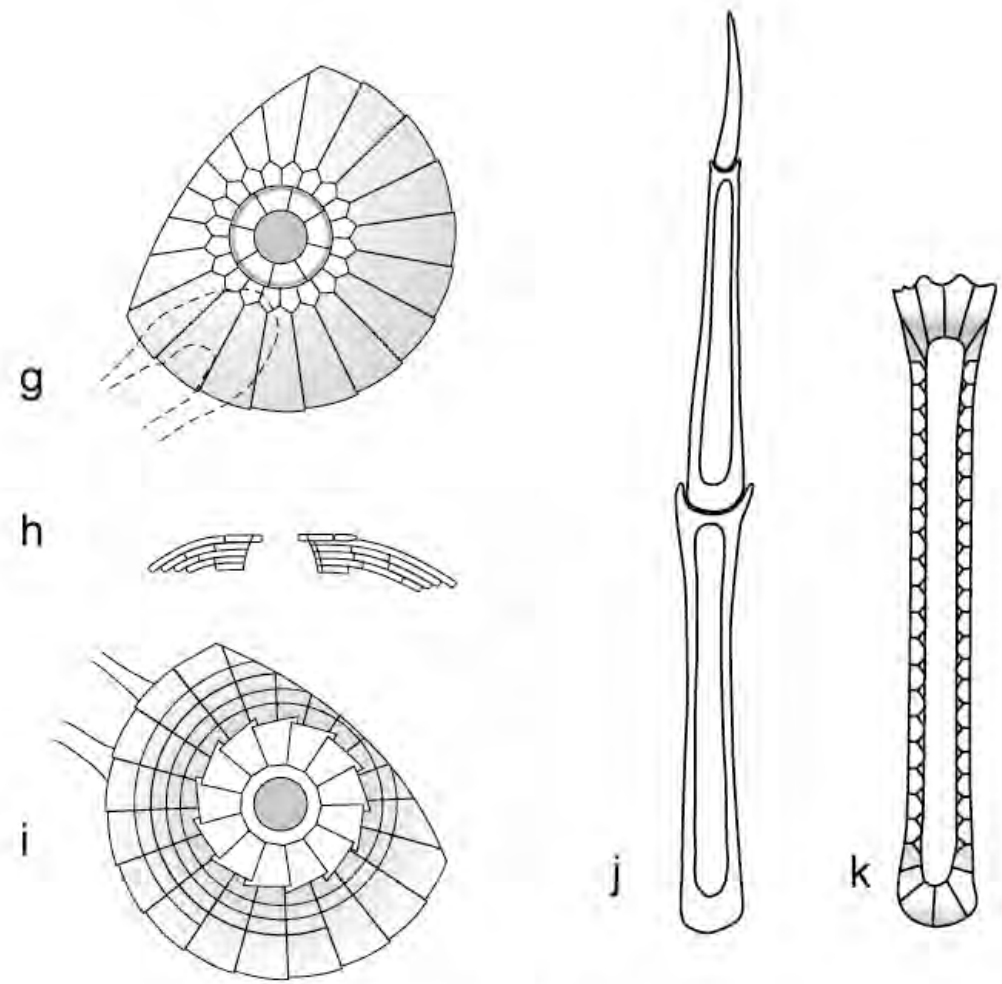

Michaelsarsia 
Fig. 10. Polar apparatus (shown open) in Calciopappus (double corolla), Michaelsarsia (compound corolla) and Ophiaster (pseudocorolla). a, c: apical views; b, d: lateral views; e: antapical view.

The outer corolla (Calciopappus) consists of a row of discoidal-truncated cyrtoliths, each with a strongly elongated, spine-shaped cyrtolith; the corolla is the inner row of truncated cyrtoliths. The compound corolla (Michaelsarsia) comprises a row of discoidal-truncated cyrtoliths, each bearing an appendage of 3 strongly elongated link-cyrtoliths; the pseudocorolla (Ophiaster) is formed of a whorl of stretched and twisted link-cyrtoliths articulated with other link-cyrtoliths that are arranged in several linear rows to form appendages. In Michaelsarsia direct attachment of the appendages to the cyrtoliths of the simple corolla requires their considerable straightening, which is achieved by additional layers of elements on their proximal side (Fig. 9h, i). In Calciopappus, whose appendages are unattached to the simple corolla, strengthening of the individual cyrtoliths occurs (and is necessary because the simple corolla drives the movements of the appendages) but does not need being as extensive as in Michaelsarsia (Fig. 9b, c). 

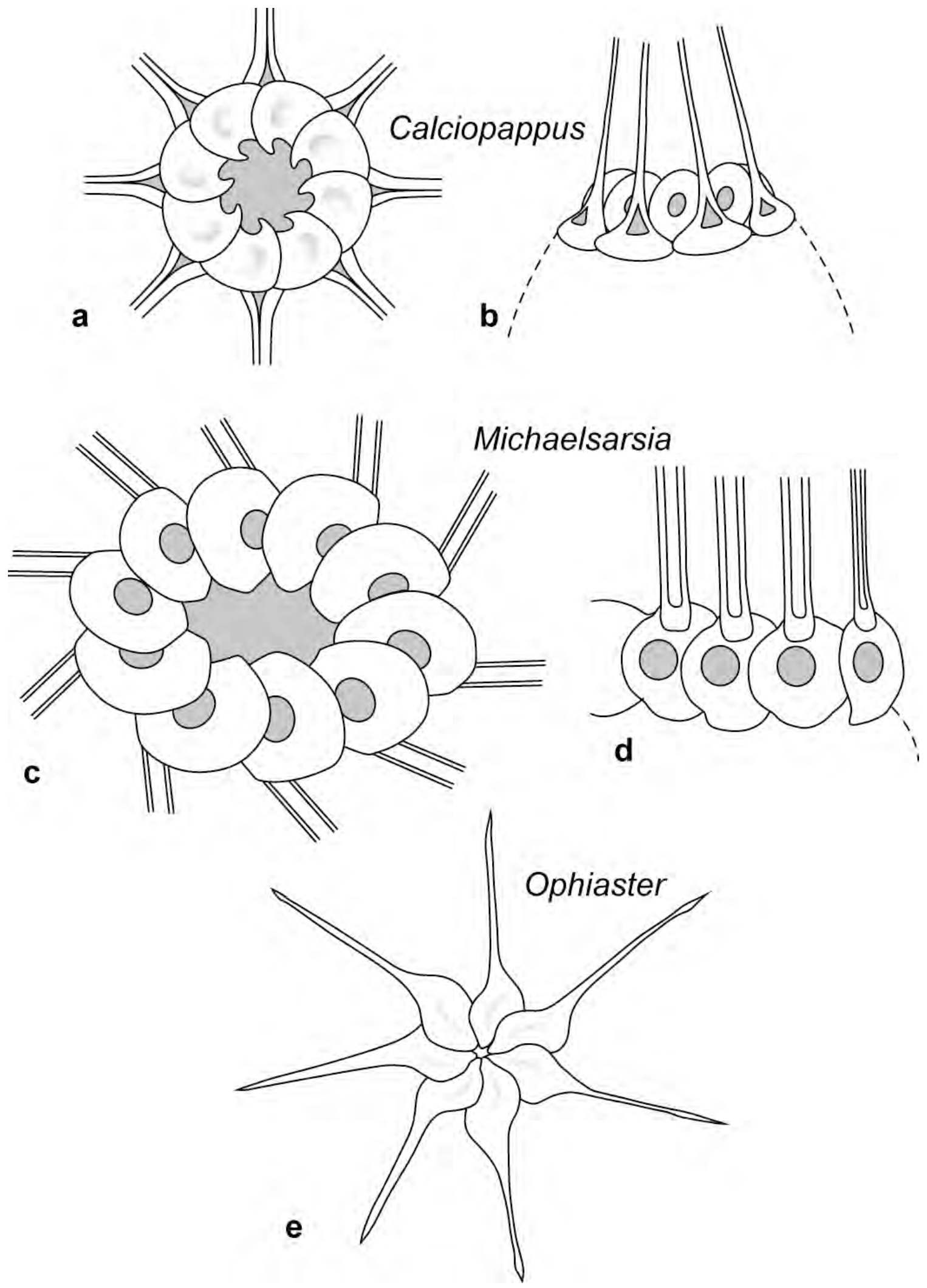
Fig. 11. Derivation of highly specialized exococcospheres (b, c, the latter a polar apparatus) from a basic complete exotheca (a). Two lines of evidence indicate that the unusual polar apparatus of Calciopappus (c) Michaelsarsia and Ophiaster are highly derived exococcospheres. One is that they consist of highly modified cyrtoliths (Figs. 8, 9); the other is that in Calciopappus and Michaelsarsia, the apparatus is firmly based on a simple whorl of cyrtoliths that is immediately comparable to the simple corolla of the $D$. molischii group, itself an exotheca restricted to the flagellar pole area (b; see P1. 1, Figs. 1-3).

Without stating that $D$. anthos is the immediate ancestor to all these species, it is reasonable to infer that all of them are related by ancestry to $D$. anthos, the latter being close to the ancestral type (a). They depart to various degree from the simple, archetype (similar to $D$. anthos) in which the cyrtoliths are circular, forming a continuous, compact exococcosphere such that dithecatism is complete. 

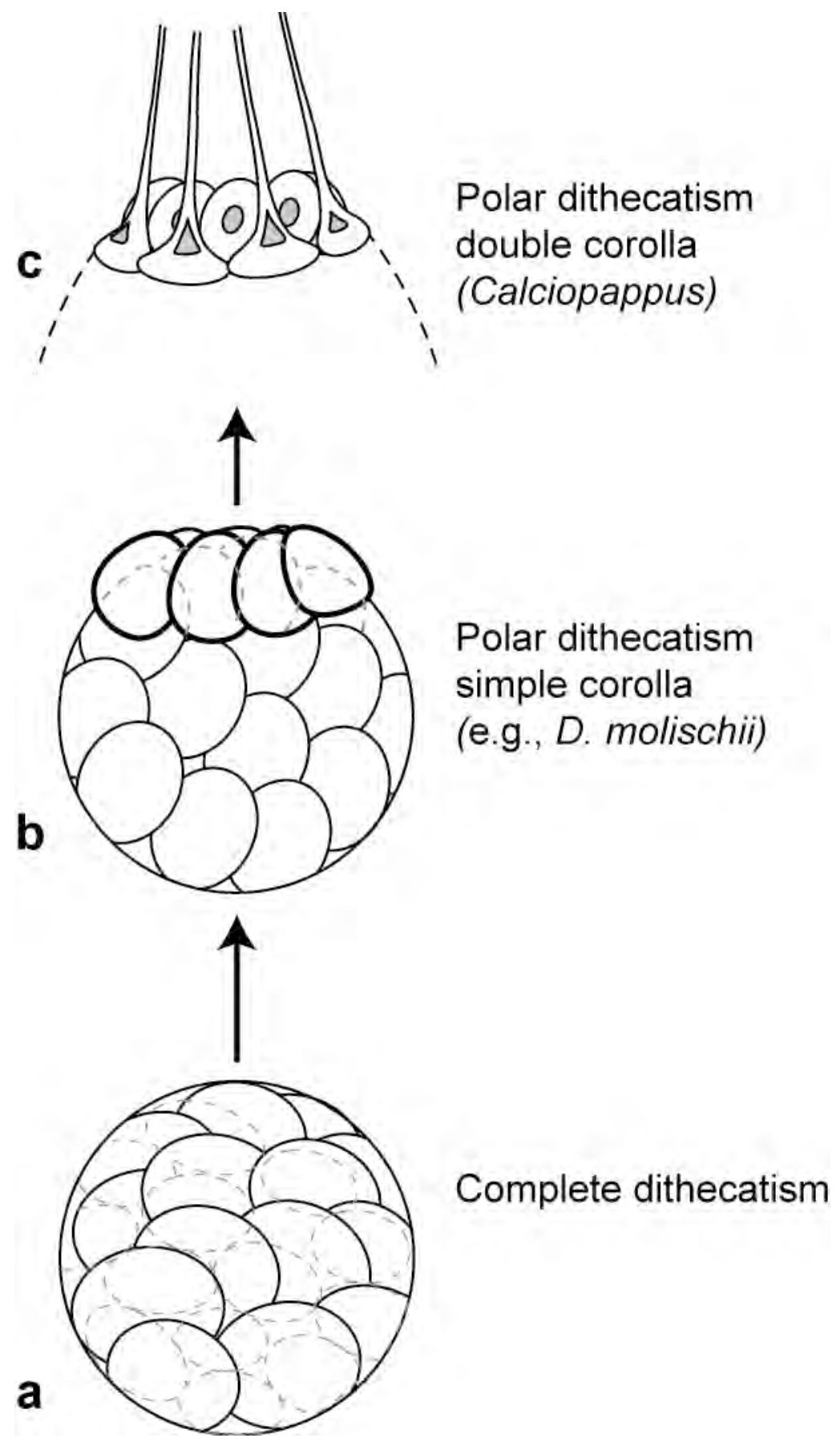
Fig. 12. Caneoliths and umbroliths in Gaarderia. a: distal view; b: cross-section; c: proximal view. These coccoliths are arranged in a spirotheca. The outermost coccoliths are large umbroliths; the innermost coccoliths are small caneoliths. A gradual transformation occurs from caneoliths to umbroliths as the size of the coccoliths increase outwards (Plate 2, Fig. 4).
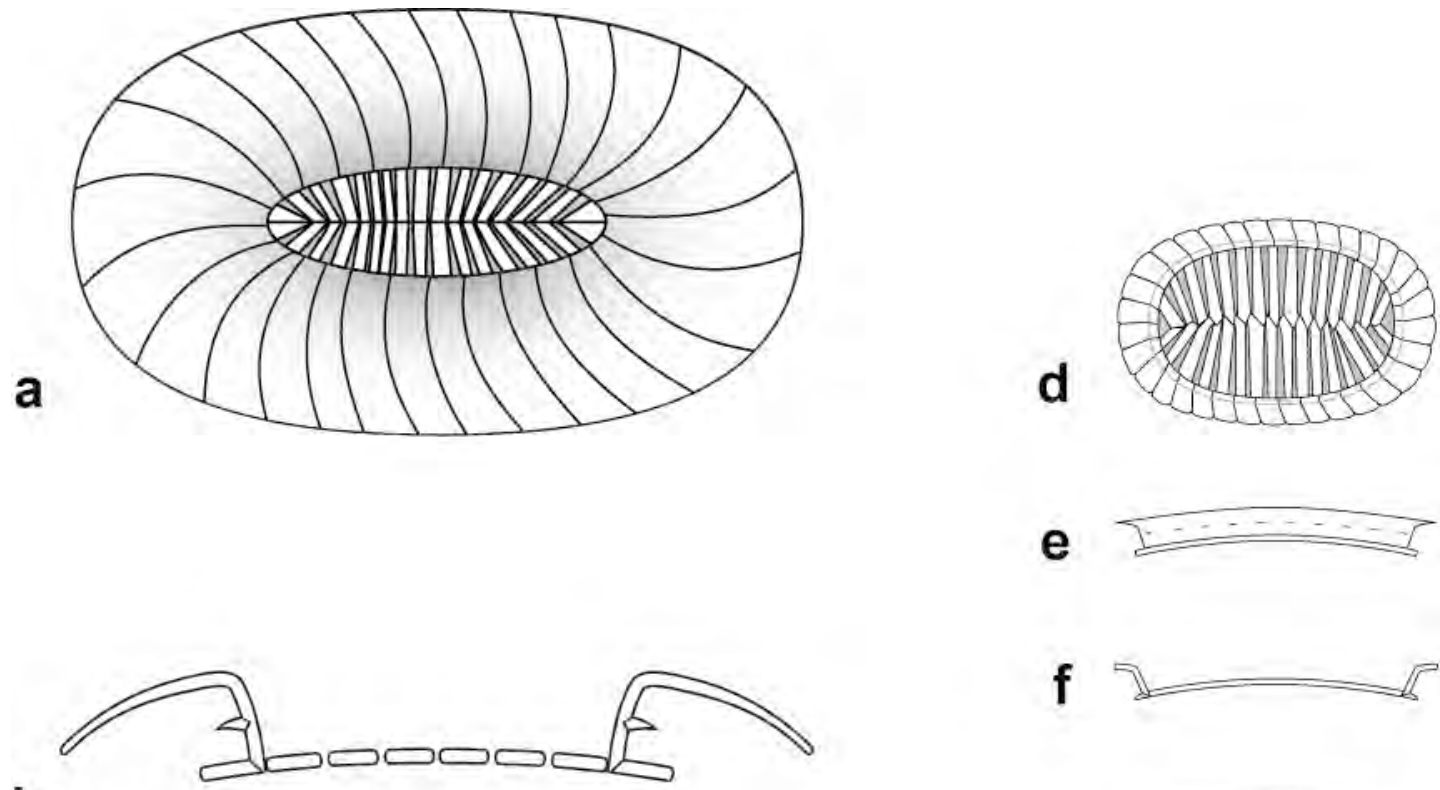

b

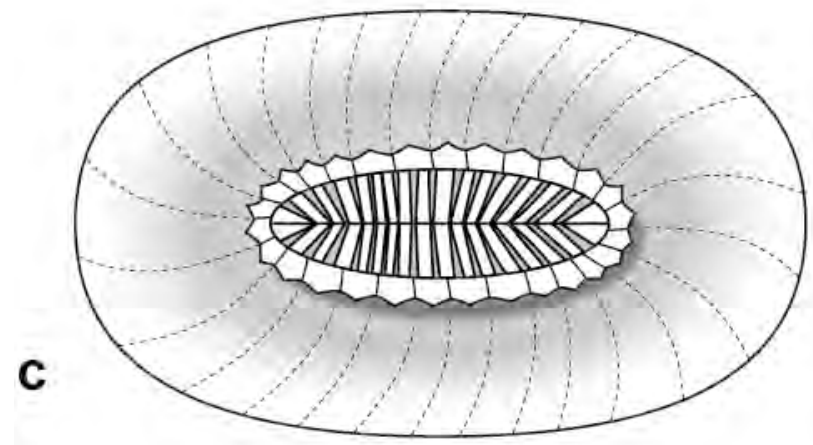

g

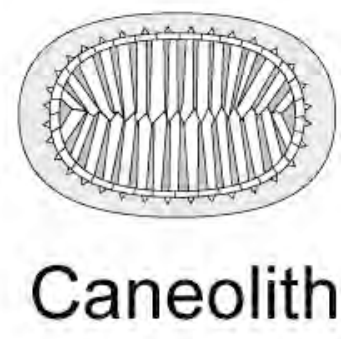

\section{Umbrolith}


Fig. 13. Cannaliths and umbelloliths in Umbellosphaera: a: distal view; b: side view; d: proximal view. The spirotheca in this genus comprises large (external) umbroliths and small (inner) cannaliths, the latter transforming progressively into the former as the size increases (Fig. 3e; Plate 2, Fig. 6; Plate 3, Figs. 1-3) 

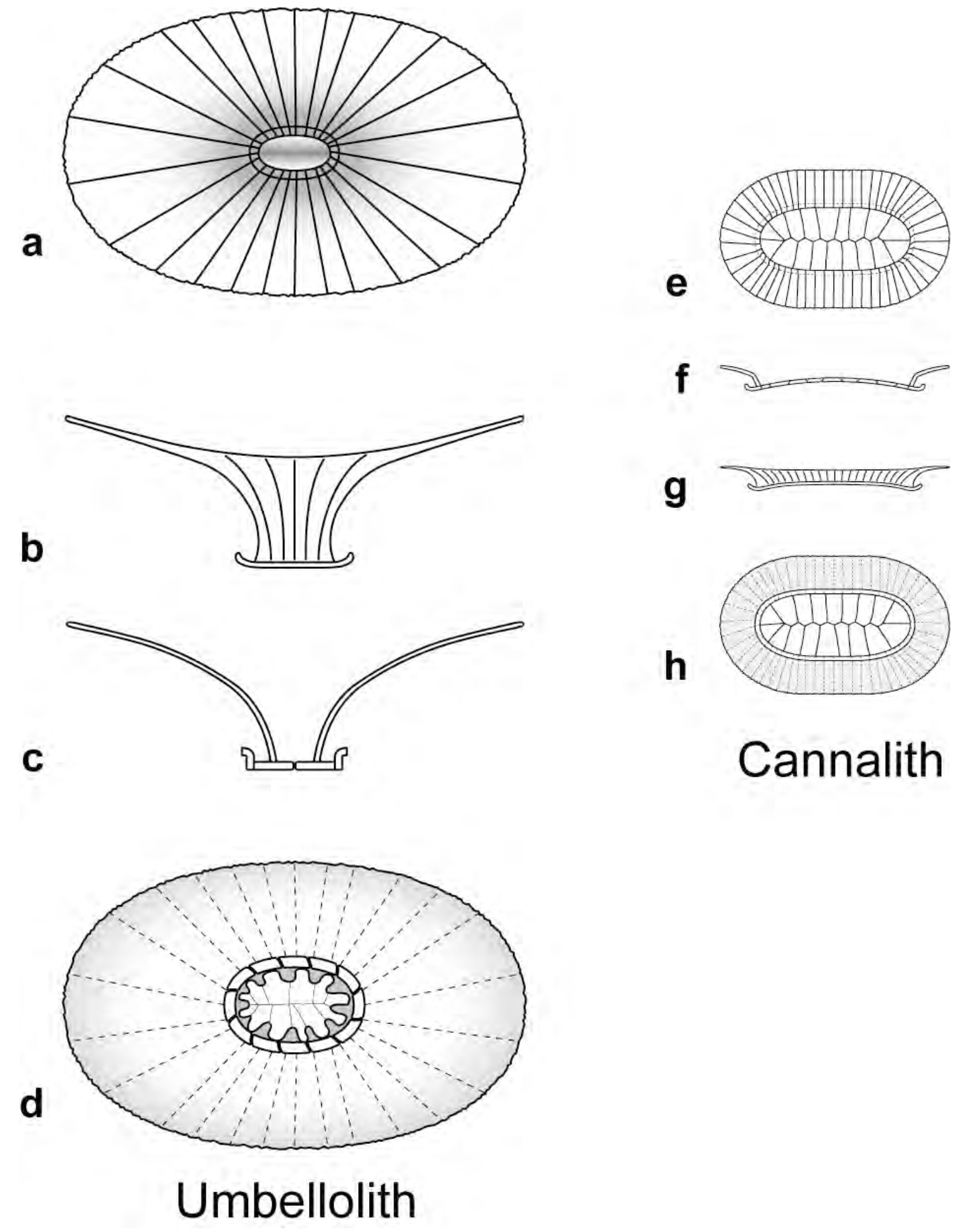
Fig. 14. Line drawing of a coccosphere of Ophiaster hydroideus showing the endotheca partly covered by the arms of the exotheca that envelop the cell in spiral fashion (drawn from Winter and Siesser, 1994, p. 134)

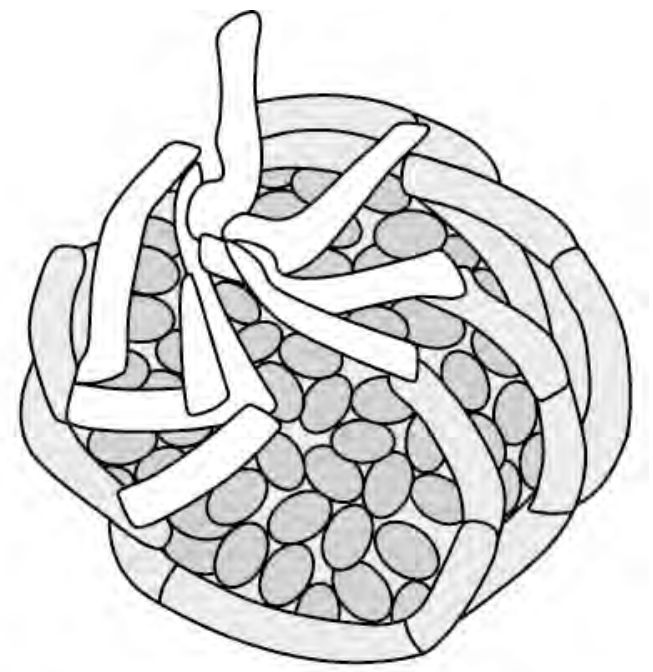

\section{Ophiaster hydroideus}


Fig. 15. Diversity (species richness) in extant genera as a fontion of cell size. Taxonomic background for these genera can be found in Young et al. (2003) and Aubry (in press). 

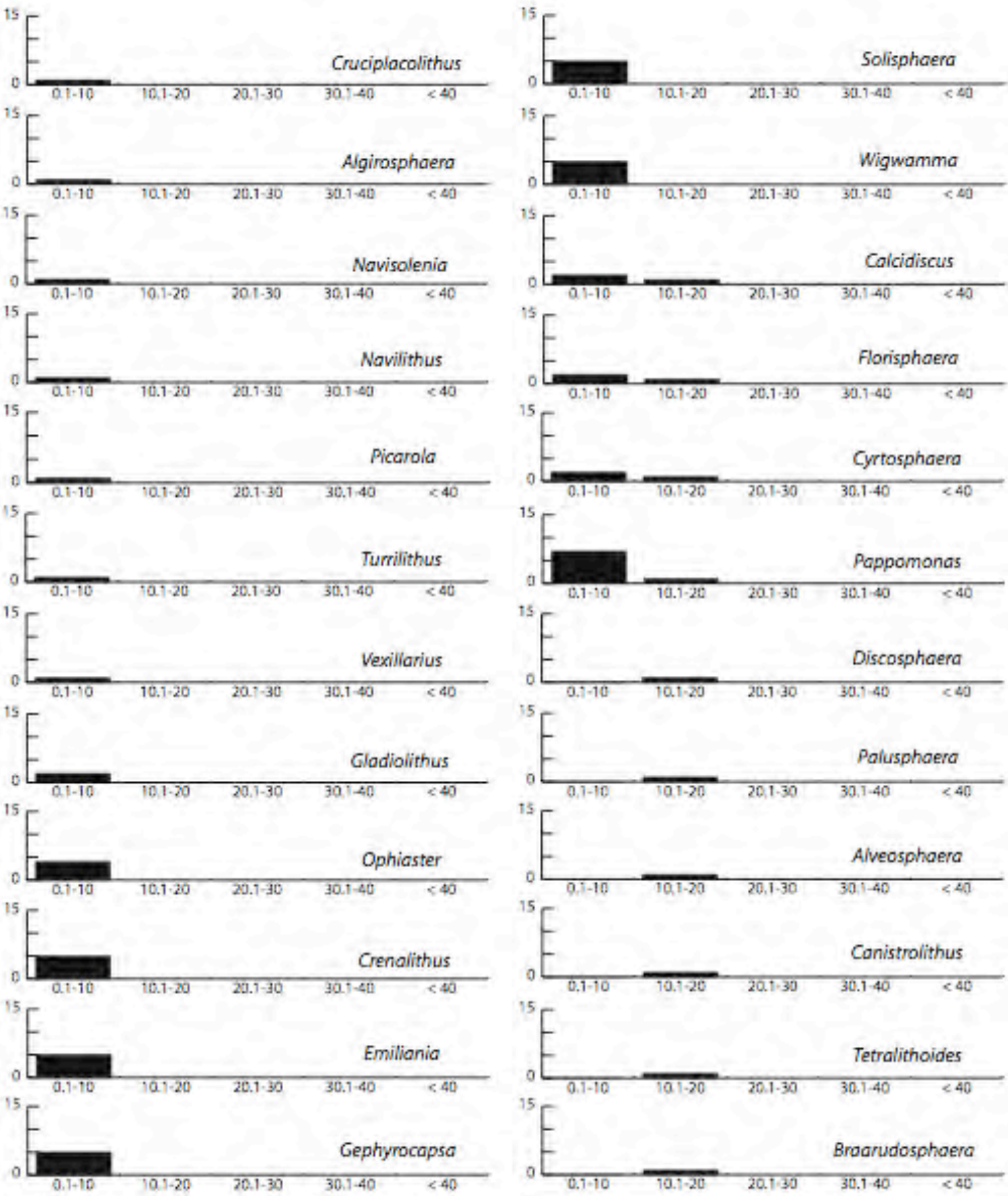

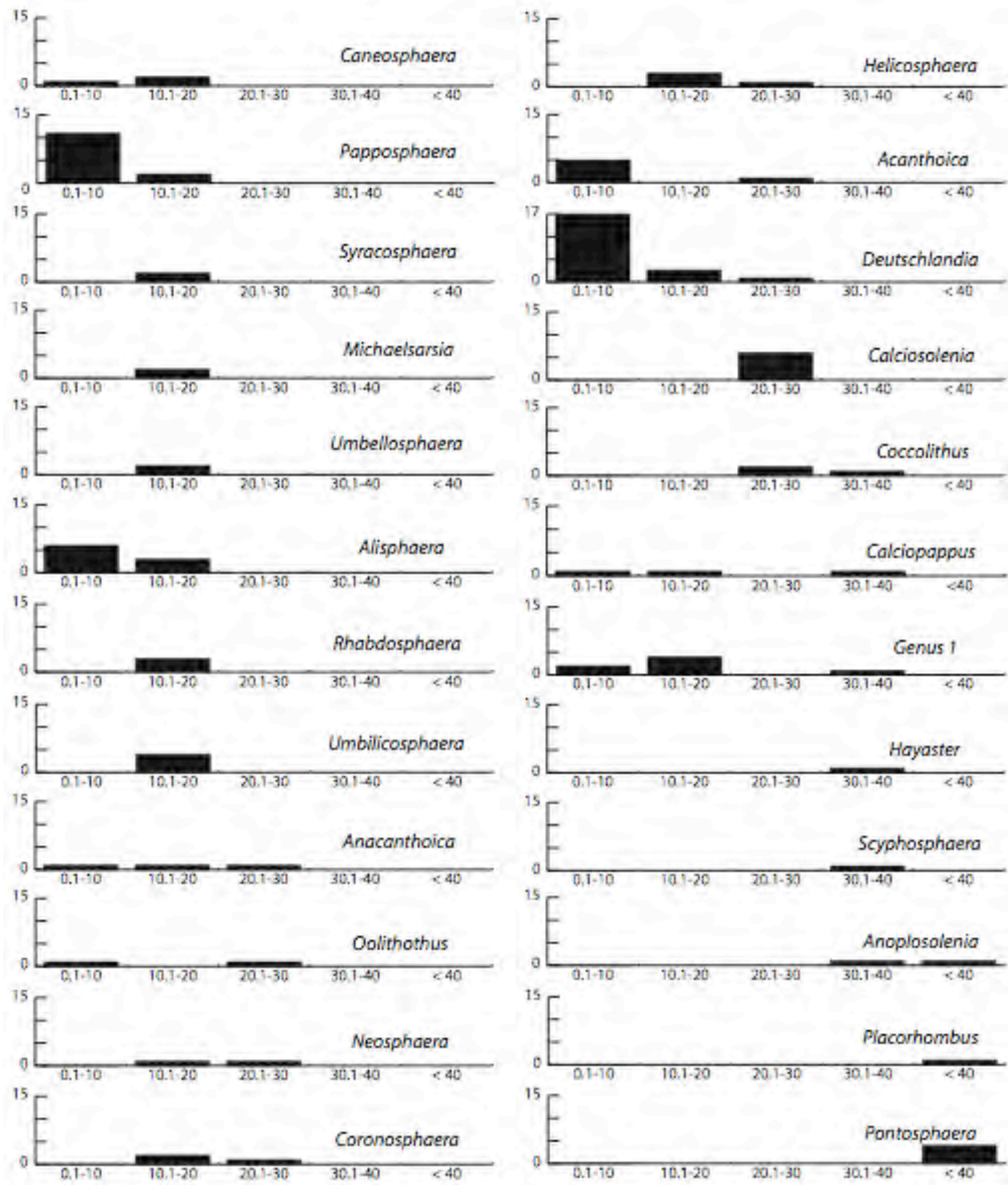
Table Caption

Table 1. Fossil representatives of the Families Deutschlandiaceae $(* *)$ and Syracosphaeraceae. Species names as given in the literature. Description, illustrations and other characters of these fossils in Aubry (in press). The noticeably smaller size of the Late Eocene caneolith may reflect the emergence of the caneolith-bearing lineage.

\begin{tabular}{|l|l|l|l|l|}
\hline $\begin{array}{l}\text { Name (as given in } \\
\text { literature) }\end{array}$ & Occurrence (age) & $\begin{array}{l}\text { Occurrence } \\
(\mathbf{z o n e})\end{array}$ & $\begin{array}{l}\text { Size } \\
(\boldsymbol{\mu})\end{array}$ & reference \\
\hline Syracosphaera sp. & Pleistocene & NN21 & 2 & Hay \& Beaudry 1973 \\
\hline D. ribosus & Pleistocene & NN21 & $2.5-3.1$ & Martini \& Müller 1972 \\
\hline Syracosphaera sp. & Pleistocene & NN20-NN21 & $4-6$ & Cohen \& Reinhardt 1968 \\
\hline S. histrica & Pleistocene & NN20-NN21 & 2,5 & Hay \& Beaudry 1973 \\
\hline S. clava & Pleistocene & NN20-NN21 & 2.8 & Hay \& Beaudry 1973 \\
\hline S. decussata & U. Pliocene-Pleist. & NN16-NN21 & 3 & Hay \& Beaudry 1973 \\
\hline D. gaarderae $* *$ & M. Pliocene & NN15 & $6-7$ & Perch-Nielsen 1980 \\
\hline D. molischii & Pliocene & NN12-NN18 & 3.8 & Stradner 1973 \\
\hline S. fragilis & M. - U. Miocene & NN6-NN11 & $4.8-6$ & Theodoridis 1984 \\
\hline Syracosphaera sp. & M. Miocene & NN7-?NN8 & $\sim 3.4$ & Müller 1974 \\
\hline Syr. sp. cf. S. pirus & M. Miocene & NN5-NN7 & $\sim 4$ & Stradner \& Fuchs 1978 \\
\hline ?S. lunularia & M. Miocene & NN5-NN7 & $7-10$ & Stradner \& Fuchs 1978 \\
\hline S. lamina & Oligocene-Miocene & NP25-NN11 & $5-6$ & De Kaenel \& Villa 1996 \\
\hline Syracosphaera sp. 1 & Oligocene & NP23-25 & $5-7$ & Okada 1990 \\
\hline S. clathrata & Oligocene & NP23 & 4.9 & Hay et al., 1967 \\
\hline Z. tanzanensis & Oligocene & NP23 & $5.1-5.4$ & Bown 2005 \\
\hline Syracosphaera sp. & U. Eocene & NP19-20 & $\sim 2$ & Bown et al. 2008 \\
\hline
\end{tabular}




\section{Plate Captions}

\section{Plate 1.}

Figures 1-4. Deutschlandia molischii (Schiller) Aubry n.c. The coccosphere exhibits polar dithecatism. The endococcosphere is composed of caneoliths. The polar exococcosphere consists of a whorl of cyrtoliths (= simple corolla) that surround the flagellar opening. In Figures 1 and 2 the exococcoliths are seen in distal view; in Figure 3 they are seen in proximal view (top right, detached). Note the truncation of each cyrtolith, resulting in reduced overlap between adjacent coccoliths. Note also the thickening of the elements on the distal side of the cyrtoliths, which may contribute to retaining preys. The sturdy helatoform caneoliths at the flagellar opening (Fig. 4) may serve as buttresses supporting the corolla, and assisting its opening and closure.

Figures 3, 4. Ophiaster formosus Gran 1912 sensu Gaarder 1967 emended Manton and Oates 1983

Figure 3: The coccosphere exhibits antapical polar dithecatism. Endococcosphere composed of caneoliths. Antapical apparatus (derived polar exococcosphere) consisting of several articulated appendages, each consisting of rows of link-cyrtoliths, the most proximal cyrtoliths of all appendages arranged in an articulated whorl (pseudocorolla). Figure 4: "Ball" formed by the antapical appendages folded on themselves. Note the absence of caneoliths.

Photographs 1, 2, 3, 5: Courtesy of Margarita Dimiza and Maria Triantaphyllou, middle Aegean Sea, eastern Mediterranean Sea.

Photographs 4, 6: Courtesy of Alicia Kahn, Indian Ocean, Melville Transect.

\section{Plate 2.}


Figures 1-3. Michaelsarsia elegans Gran in Murray and Hjort 1912 emended Manton, Bremer and Oates, 1984

Figure 1. The whole organism in side view. Endococcosphere of caneoliths. Apical apparatus (= derived polar exococcosphere) consisting of a whorl of discoidal-truncated cyrtoliths (= simple corolla, seen in side view in the first plane) surrounding the flagellar opening. To each discoidal-truncated cyrtolith is attached an appendage consisting of three articulated link-cyrtoliths (= coumpound corolla; right). Background with numerous link-cyrtoliths separated from their discoidal-truncated cyrtolith.

Figure 2. Apical apparatus (derived exococcosphere) in apical view. Note the overlap between the discoidal-truncated cyrtoliths, the attachement of the appendages on their distal side, and the articulated link-cyrtoliths forming the appendages. Simple corolla is slightly disturbed.

Figure 3. Detail of figure 1. Note the shape of the link-cyrtoliths, and the presence of an organic membrane spread across their center. Note also the organic membrane in the central opening of the discoidal-truncated cyrtoliths.

Figure 4. Spirothecate coccosphere of Gaarderia corolla (Lecal) Kleijne 1993. The shape and size of the coccoliths change around the cell, and also from the underlayer to the upper layer. There is no endotheca and exotheca proper. The largest coccoliths (umbroliths) with broad flange are located around the flagella opening. The underlayer consists of caneoliths. Note the thin membrane occurring in the center of the umbroliths.

Figures 5. Spirothecate coccosphere (partly desintegrated) of Umbellosphaera irregularis (Fig. 5; partly desintegrated) and U. tenuis Type D. Note the funnel-shape of the umbelloliths of $U$. irregularis, and the differences in their size.

Figure 6. Spirothecate coccosphere of Umbellosphaera tenuis (Kamptner) Paasche in Markali and Paasche 1955 type 4 Kleijne 1993. Note the pattern of dichotomized ridges and troughs on the distal side of umbelloliths. 
Photographs 1, 3, 5, 6: Courtesy of Alicia Kahn, Indian Ocean, Melville Transect.

Photographs 2, 4: Courtesy of Margarita Dimiza and Maria Triantaphyllou, middle Aegean Sea, eastern Mediterranean Sea.

\section{Plate 3.}

Figures 1-3. Partly disintegrated spirothecas of Umbellosphaera tenuis (Kamptner) Paasche in Markali and Paasche 1955 type 1 Kleijne 1993. Note the differences in size and morphology of the coccoliths (in proximal and distal views), and the distal thickenings along the sutures and the asperous distal surface.

Figure 4. Coccosphere of Discosphaera tubifera (Murray and Blackmann) Ostenfeld 1900. Although the stems are partly detached from their base, the coccosphere is clearly composed of rhabdoliths of different lengths.

Figure 5. Coccosphere of Turrilithus latericioides Jordan, Knappertsbusch, Simpson, and Chamberlain 1991. Tiny food particles $(<0.11 \mu)$ may settle in the deep, narrow pyramidal-shaped coccoliths.

Figure 6. Dimorphic endococcosphere of Syracosphaera pulchra Lohmann 1902. Dithecatism is facultative in this species. The stem-bearing caneoliths around the flagellar pole may protect the base of the flagella, and also help retaining food particles.

Photographs: Courtesy of Alicia Kahn, Indian Ocean, Melville Transect. 


\section{Plate I}
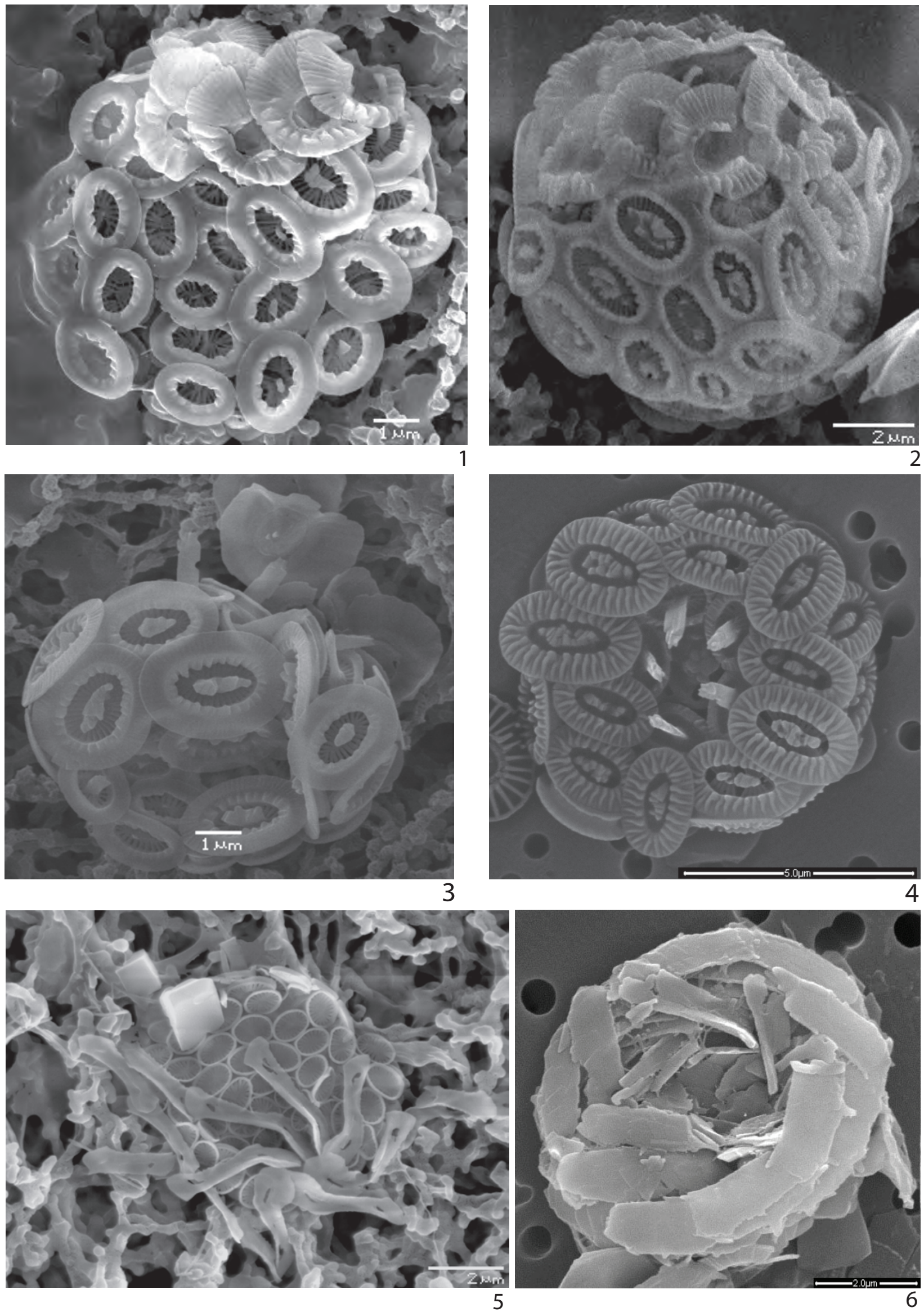
Plate II
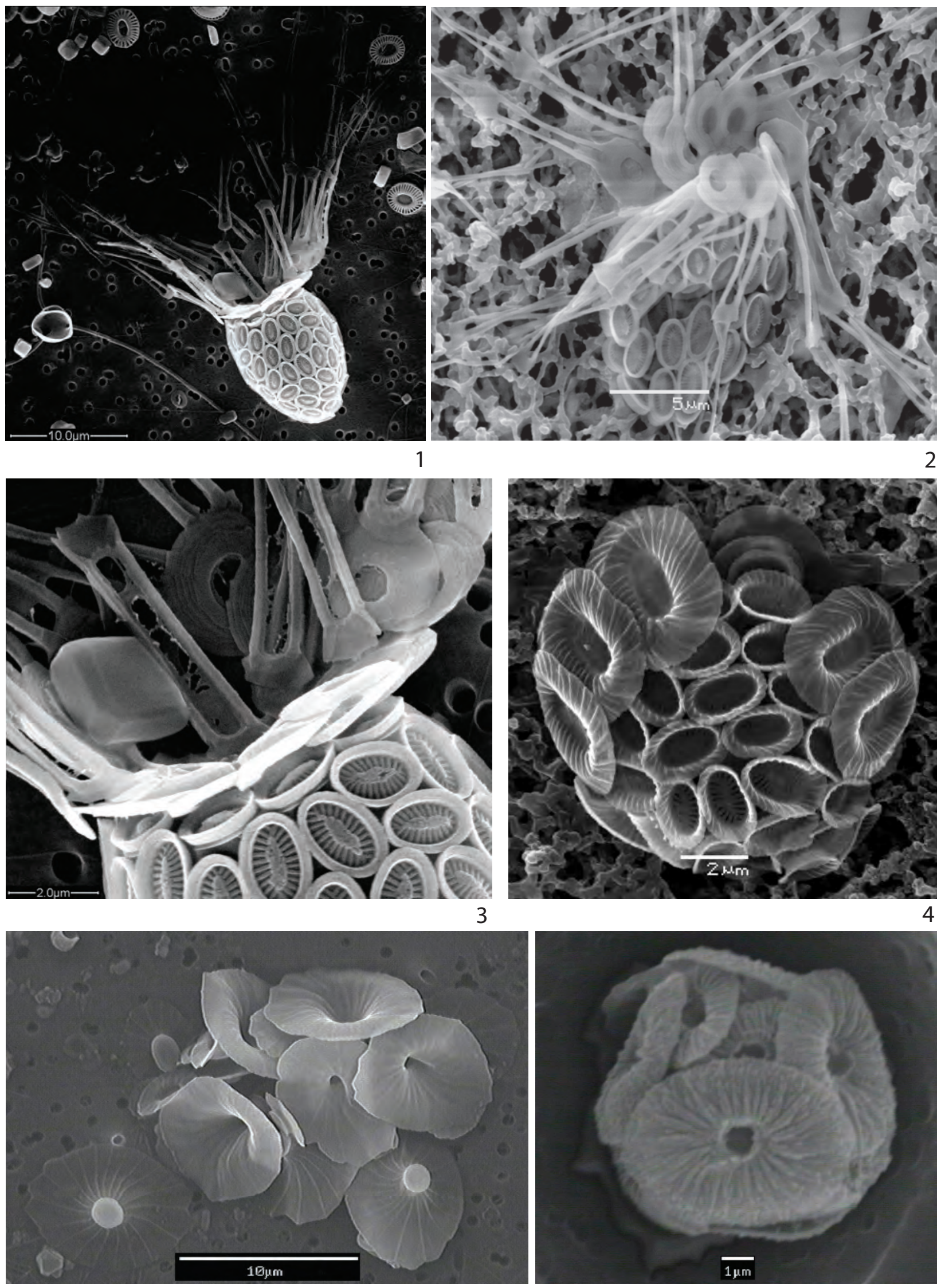
Plate III
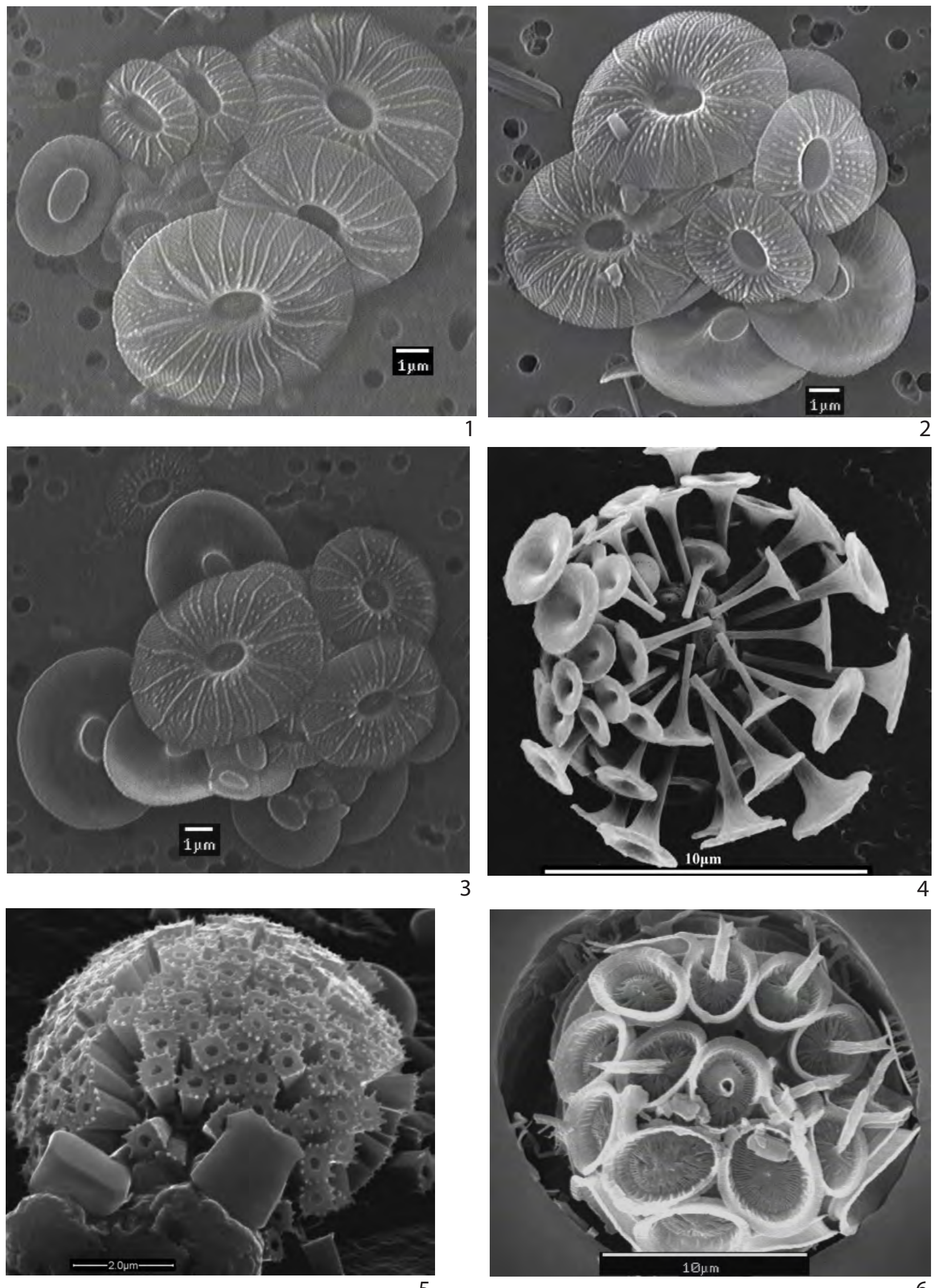


\section{Appendix 1. Overview of the taxa considered in this paper}

This study is an outgrowth of a revision (Aubry, in press a) of all taxa with caneolith- and umbellolith-bearing coccospheres, based on their original descriptions and the assessment of subsequent revisions and emendations, including that of major scanning and transmission electron microscope (SEM and TEM) studies (in particular, Cros 2000; Cros and Fortuño, 2002; Gaarder, 1967; Gaarder et al., 1954; Gaarder and Heimdal, 1977; Halldal and Markali, 1955; Heimdal and Gaarder, 1981; Kleijne, 1993; Manton and Oates, 1983; Manton et al., 1984; Young et al., 2003). As explained in Aubry (1998), the morphostructure of coccoliths describes the number and mutual arrangement of cycles of strongly modified rhombohedrons (= elements). In coccolithophorids, morphostructure underlies rigourous generic taxonomy whereas morphology alone constitutes the basis for species taxonomy.

\section{Families Deutschlandiaceae and Syracosphaeraceae}

These families are characterized by the secretion in all species of 'caneoliths' which form the layer closer to the cell surface in dithecate and "spirothecate" species.

Caneolith-bearing species are commonly distributed among four genera, a majority (50 species) being assigned to Syracosphaera Lohmann 1902 (Appendix 2). A recent tendency has been to use a by-default taxonomy for these 50 taxa, based on the morphology of the caneoliths and without consideration of the exococcoliths (see Young et al., 2003). However, detailed analysis of the morphostructure of the latter supports division of Syracosphaera sensu lato into several groups (= genera) (see also Cros, 2000) as in early studies (Lohmann, 1902; Kamptner, 1928; Hay, 1977; Heimdal and Gaarder, 1981). In addition, dithecatism and monothecatism should be regarded as basic generic characters, as in other families (e.g., Rhabdosphaeraceae). On the basis of these two criteria (morphostructure of exococcoliths; dithecatism/monothecatism), 9 genera (Calciopappus, Caneosphaera, Coronosphaera, Deutschlandia, Gaarderia, Genus A, Michaelsarsia, Ophiaster, Syracosphaera) are distributed among 2 families (Deutschlandiaceae, Syracosphaeraceae). The morphologic and structural characters of species in these families are summarized below.

\section{Family Deutschlandiaceae.}


The Family Deutschlandiaceae includes 4 genera, Deutschlandia, Calciopappus, Michaelsarsia, Ophiaster. In the genus Deutschlandia, the exococcosphere is comprised of typical cyrtoliths - basically thin, sligthly concavo-convex, often circular coccoliths. Typically comprised of three concentric cycles, cyrtoliths exhibit a remarkable structural unity (Aubry, in press; Figs. 7, 8). The outer marginal cycle is generally prominent, consisting of $\sim 20$, quadrangular or elongated elements; the inner marginal cycle is typically comprised of radial, rod- or lath-shaped elements that alternate with those of the outer cycle. The central cycle may be comprised of a few to many elements, arranged regularly or not.

Cyrtoliths exhibit an astonishing morphologic diversity ranging, in Deutschlandia, from discoidal to wheel-shaped to contorted (Figs. 7, 8). In plan view they may be circular, smoothly elliptical, polygonal, elliptical truncated; the margin may be extended into one or two wings resulting from lateral distortion. All are tiny in extant species, ranging between 2 and $5.5 \mu$ with a mean of $3 \mu$. Most are thin and delicate, but some are so thin as to espouse the relief of the caneoliths in the underlying endotheca; others are thick and robust; still others are thickened locally by superposed concentric layers of elements. Sutures between adjacent elements are distinct except in robust morphologies. Two groups of cyrtoliths, easily related to an archetype typified by $D$. anthos, are readily distinguished; one is typified by D. nodosa (Fig. 7), the other by D. molischii (Fig. 8).

Despite appearance, and as shown by structure, the coccoliths that form the polar apparatus in Calciopappus, Ophiaster and Michaelsarsia are cyrtoliths, but strongly modified compared with those of Deutschlandia, either through considerable lengthwise stretching (linkand spine-cyrtoliths; Fig. 9; P1. 1, Figs. 5, 6; Pl. 2, Figs. 2, 3) or through remarkable thickening (discoidal truncated cyrtoliths; Fig. 9; P1. 2, Figs. 2, 3).

\section{Family Syracosphaeraceae}

Four genera are assigned to the Family Syracosphaeraceae. The genera Caneosphaera and Coronosphaera include species with monothecate coccospheres. Syracosphaera s.st. includes (2) species with an exotheca of complex caneoliths (as described for S. pulchra, Inouye and Pienaar, 1988; Young et al., 2004). Genus A is informally introduced here for (9) species 
recognized by Cros (2000) to possess an exococcosphere of caneoliths that are of simpler structure than those of the endotheca. This genus is insufficiently documented as yet. The reader is referred to Aubry (in press) for the description of these taxa that are not discussed in this paper.

Gaarderia is also monospecific. Its coccosphere is sprirothecate, consisting of caneoliths (inner coccoliths) and umbroliths (outer coccoliths). The latter are umbrella-shaped, with a broad, recurved rim surrounding a narrow and elongate central depression. Proximally, a narrow cycle surrounds the central area filled with radiating, disjunct lath-shaped elements (Fig. 12a-c). Importantly, these central elements are inserted between the broad rim elements. The innermost, elliptical caneoliths also have a recurved rim and a central area spanned by radiating lath-shaped elements - but the rim is very narrow and the central area is broad (Fig. 12d-g). The interesting feature is that umbroliths and caneoliths exhibit the same structure but the proportions of the different structural components are reversed. Thus, the central area is prominent in the caneoliths, reduced and narrow in the umbroliths. Conversely, the margin is prominent in the latter. A few coccoliths, exhibiting intermediate size, morphology and structure between the two are neither umbroliths or caneoliths - or are both. Their intermediate location around the cell between typical caneoliths and umbroliths, is definitive evidence that the umbroliths are derived from the caneolith-structure. As the coccoliths are roughly arranged along a few spirals, the coccosphere is referred to as "spirothecate".

\section{Family Umbellosphaeraceae}

This monogeneric family includes unusual, spirothecate coccospheres. The outer coccoliths, or umbelloliths, are mushroom-shaped, with a tall, thin, recurved, distally flaring rim that surrounds a narrow subcircular central depression. Their general appearance is that of umbroliths (compare Figs. 12a-c and 13a-d). The inner coccoliths, or cannaliths, have a narrow rim surrounding an elliptical central area filled with broadly radiating wedge-shaped elements. Their general appearance is the same as that of Gaarderia-caneoliths (compare Figs. 12d-g and 13e-h). As in G. corolla, a reversal of the proportions between the structural components of 
umbelloliths and cannaliths occur. Also as in this species, there are a few umbelloliths that are half way between being cannaliths and umbelloliths. This is especially true for species with radial thickenings on the rim of the umbelloliths. In them, a few coccoliths have the size and $\mathrm{rim} /$ central area proportions characteristic of cannaliths but radial thickenings as in umbelloliths. These coccoliths are located on the coccosphere at the transition between typical cannaliths and typical umbelloliths.

Three lines of evidence concur to indicate that umbelloliths and umbroliths on the one hand, and cannaliths and caneoliths on the other hand, are, at the very least, analogous. They have in common 1) broad morphological appearance, 2) same location on coccosphere with respect to coccolith type, and 3) reversed scaling between coccolith types (umboliths vs. caneoliths and umbelloliths vs. cannaliths). The spirothecate character of the coccosphere further strengthens the morphologic similarity between Umbellosphaera and Gaarderia species. There are two possible explanations for these extreme similarities. One is morphologic convergence, as implied by taxonomic schemes that separate the two genera at the order rank (e.g., Cros and Fortuño, 2002; Young et al., 2003). The other is phylogenetic closeness, as indicated by taxonomic schemes that unite the two genera at the family or subfamily level (e.g., Kleijne, 1993).

Morphologic convergence is widespread among extant coccolithophorids, and may result in high degrees of similarity between taxa of different orders, as for instance between some Deutschlandia species (Order Syracosphaerales) and Emiliana huxleyi (Order Isochrysidales) (Aubry, 2007). Convergence to an extreme degree between Gaarderia and Umbellosphaera thus cannot simply be dismissed. However, one character - the shape of the rim elementsgives a clue that convergence is not operational here. Characteristically, the rim of the umbroliths (Gaarderia) consists of elements with width differing along the sides and at the poles. At the poles there are 3 to 4 very broad elements with diverging sutures. On both long sides the elements are narrow and with subparallel sutures (Fig. 12a, c). The same character occurs in the umbelloliths (Umbellosphaera) (Fig. 13a,d). This is obvious in U. irregularis, and in $U$. tenuis in which the distal surface of the rim is not covered by thickened ridges. Such a configuration is rare. It is characteristically found in the Mesozoic and Paleogene coccoliths of 
the Family Biscutaceae (see Aubry, in press b). Without implying a distant phylogenetic relationship between this extinct family and two extant taxa, this points to the unlikely occurrence of this character; its occurrence thus supports a close phylogenetic relation between Gaarderia and Umbellosphaera. Molecular biology will confirm (or negate) that umbelloliths and umbroliths on the one hand, and caneoliths and cannaliths on the other, are not only analogous, but also homologous. Cannaliths are easily derived from caneoliths, through structural simplification. 


\section{Appendix 2. Taxonomic framework for caneolith-secreting species. Full references to authors in Aubry (in press).}

All monothecate coccospheres (genera Caneosphaera, Coronosphaera), the endotheca of all dithecate coccospheres (genera Calciopappus, Deutschlandia, Michaelsarsia, Ophiaster, Syracosphaera), the inner part of spirothecate coccospheres (genus Gaarderia) and both the endo- and exotheca of the provisional genus A consist of caneoliths, a readily identified morphostructural group typical of the Families Coronosphaeraceae, Deutschlandiaceae, and Syracosphaeraceae. The exotheca of Calciopappus, Deutschlandia, Michaelsarsia and Ophiaster consists of cyrtoliths; that of Syracosphaera of tololiths; of Genus A of caneoliths; and of Gaarderiella of umbroliths. The coccospheres of Umbellosphaera, a genus closely related to Gaarderia is comprised of cannaliths (inner coccoliths) and umbelloliths (outer coccoliths). The monothecate taxa (Caneosphaera and Coronosphaera) are not discussed in this paper. Fossil taxa are represented by caneoliths, broadly assigned to Syracosphaera. The generic assignment of the middle Pliocene species Deutschlandia gaardera is correct, the fossil coccolith being a cyrtolith. Information on these taxa compiled in Aubry (in press). The description of new taxa is given in Appendix 3.

$\underline{\text { Extant taxa }}$

\section{Order Syracosphaerales}

\section{Family Deutschandiaceae Kamptner 1928 emend.}

Calciopappus Gaarder and Ramsfjell emended Manton and Oates 1983

Calciopappus caudatus Gaarder and Ramsfjell 1954

Calciopappus rigidus Heimdal in Heimdal and Gaarder 1981

Calciopappus sp. 1 Cros and Fortuno 2002

Deutschlandia Lohmann 1912 emended Gaarder 1981, emend 
Deutschlandia ampliora (Okada and McIntyre) Aubry n.c. (= Syracosphaera ampliora Okada and McIntyre 1977, p. 19, 20, pl. 7, fig. 9)

Deutschlandia anthos Lohmann, 1912

Deutschlandia bannockii (Cros, Kleijne, Zeltner, Billard and Young 2000) Aubry n.c. (=

Syracosphaera bannockii (Borsetti and Cati 1976) Cros, Kleijne, Zeltner, Billard and

Young 2000, p. 29, pl. 7, figs. 1-6; = Sphaerocalyptra bannocki Borsetti and Cati 1976,

p. 212, pl. 13, fig. 406)

Deutschlandia borealis (Okada and McIntyre) Aubry n.c. (= Syracosphaera borealis Okada and McIntyre 1977, p. 20, pl. 10, fig. 8)

Deutschlandia corrugis (Okada and McIntyre) Aubry n.c. (= Syracosphaera corrugis Okada and McIntyre 1977, p. 21, 22, P1. 8, Figs. 3, 6)

Deutschlandia delicata (Cros, Kleijne, Zeltner, Billard, and Young) Aubry, n.c. (=

Syracosphaera delicata Cros, Kleijne, Zeltner, Billard, and Young 2002, p. 29, 31, pl. 10, figs. 1-6; = Corisphaera sp. type B of Kleijne 1991)

Deustchandia elatensis (Winter) Aubry, n.c. (=Syracosphaera elatensis Winter 1979, p. 207208, Pl. 3, Figs. 11-13)

Deutschlandia exigua (Okada and McIntyre) Aubry n.c. (= Syracosphaera exigua Okada and Mcintyre 1977, p. 21, pl. 8, figs. 10-12)

Deutschlandia gaarderae Perch-Nielsen, 1980

Deutschlandia lamina (Lecal-Schlauder) Aubry 2007 (= Syracosphaera lamina Lecal-Schlauder 1951 , p. 286, 287, figs. 23, 24)

Deutschlandia marginaporata (Knappertsbusch) Aubry n.c. (= Syracosphaera marginaporata

Knappertsbusch 1993, p. 72, 74, pl. 2, figs. 1-3; = Syracosphaera sp. H Kleijne 1993)

Deutschlandia molischii (Schiller) Aubry n.c. (=Syracosphaera molischii Schiller 1925, p. 21, figs. k/a-e)

Deutschlandia nana (Kamptner) Aubry n.c. (= Pontosphaera nana Kamptner 1941, p. 73, 79, pl.

3, figs. 31-33; = Syracosphaera sp. type A of Kleijne , 1991)

Deutschlandia nodosa (Kamptner) Aubry n.c. (= Syracosphaera nodosa Kamptner 1941)

(=Pontosphaera variabilis Halldal and Markali 1955, p. 12, 13, P1. 12, Figs. 1-3)

Deutschlandia orbiculus (Okada and McIntyre) Aubry n.c. (=Syracosphaera orbiculus Okada and McIntyre 1977, p. 25, pl. 9, figs. 4-6) 
Deutschlandia ossa (Lecal) Aubry n.c. (= Syracosphaera ossa (Lecal) Loeblich and Tappan 1968; = Syracorhabdus ossa Lecal 1966, inv.)

Deutschlandia rotula (Okada and McIntyre) Aubry n.c. (= Syracosphaera rotula Okada and McIntyre 1977, p. 27, pl. 9, figs. 9, 12)

Deutschlandia tumularis (Sánchez-Suárez) Aubry n.c. (= Syracosphaera tumularis SánchezSuárez 1990, p. 157, 158, Figs. 4A-F)

Deutschlandia sp. type L (Kleijne) Aubry n.c. (= Syracosphaera sp. type L of Kleijne 1993) Deutschlandia sp. type J (Kleijne) Aubry n.c. (= Syracosphaera sp. type J Kleijne 1993, p. 244, pl. 5, fig. 3)

Deutschlandia sp. type K (Kleijne) Aubry n.c. (= Syracosphaera sp. type K Kleijne 1993, p. 244, pl. 6, fig. 11)

Deutschlandia sp. aff to D. orbiculus (spherical) (= Syracosphaera sp. aff. to S. orbiculus (spherical) in Cros and Fortuño 2002

Deutschlandia sp. aff to D. orbiculus (ovoid) (= Syracosphaera sp. aff. to S. orbiculus (ovoid) in Cros and Fortuño 2002

Deutschlandia sp. II cf S. epigrosa (Kleijne) Aubry n.c. (= Syracosphaera sp. II cf. S. epigrosa Kleijne 1993, p. 237, pl. 4, fig. 3; = Syracosphaera sp. (slender) Cros and Fortuño, 2002).

Deutschlandia sp. cf. D. marginaporata Aubry n.c. in Young et al., 2003

Michaelsarsia Gran 1912 emended Manton, Bremer and Oates 1984

Michaelsarsia adriaticus (Schiller 1914) Manton, Bremer and Oates 1984 (= Halopappus adriaticus Schiller 1914)

Michaelsarsia elegans Gran in Murray and Hjort 1912 emended Manton, Bremer and Oates, 1984

Ophiaster emended Manton and Oates 1983

Ophiaster formosus Gran 1912 sensu Gaarder 1967 emended Manton and Oates 1983

Ophiaster formosus var. inversus Manton and Oates 1983

Ophiaster hydroideus (Lohmann 1903) Lohmann 1913 emended Manton and Oates 1983 (= Meringosphaera hydroideus Lohmann 1903)

Ophiaster minimus Manton and Oates 1983

Ophiaster reductus Manton and Oates 1983 


\section{Family Syracosphaeraceae (Lohmann 1902) Lemmerman 1903 emend.}

Caneosphaera Gaarder in Gaarder and Heimdal 1977 ex Jordan and Green 1994

Caneosphaera dilatata (Heimdal in Gaarder and Heimdal) (= Caneosphaera halldalii f. dilatata Heimdal in Gaarder and Heimdal 1977)

Caneosphaera epigrosa (Okada and McIntyre) Aubry n. c. (= Syracosphaera epigrosa Okada and Mcintyre 1977, p. 20, 21, Pl. 7, Figs. 5, 6)*

Caneosphaera halldali (Gaarder ex Jordan and Green) Aubry n. c. (= Syracosphaera halldali Gaarder ex Jordan and Green 1994)

Caneosphaera protrudens (Okada and McIntyre) Aubry n. c. (= Syracosphaera protrudens Okada and McIntyre 1977, p. 26, 27, Pl. 10, Fig. 3)*

Coronosphaera Gaarder in Gaarder and Heimdal 1977

Coronosphaera binodata (Kamptner 1927) Gaarder and Heimdal 1977 (= Syracosphaera mediterranea var. binodata Kamptner 1927; = Syracosphaera binodata Kamptner 1937)

Coronosphaera maxima (Halldal and Markali) Gaarder in Gaarder and Heimdal 1977 (=Syracosphaera maxima Halldal and Markali, 1955)

Coronosphaera mediterranea (Lohmann 1902) Gaarder 1977 (= Syracosphaera mediterranea Lohmann, 1902)

Coronosphaera sp. Young et al. 2003

Gaarderia Kleijne 1993

Gaarderia corolla (Lecal) Kleijne 1993 (= Syracolithus corolla Lecal 1966; = Syracosphaera corolla Lecal 1966*)

Genus A informal

Genus A florida (Sánchez-Suárez) Aubry n.c (= Syracosphaera florida Sánchez-Suárez 1990, p. 156, 157, Figs. 3A-F; = Syracosphaera sp. type F Kleijne 1993; =Syracosphaera $\mathrm{sp.}$ Kling 1975)

Genus A noroitica (Knappertsbusch) Aubry n.c. (= Syracosphaera noroitica Knappertsbusch 1993, orthog. emend. Jordan and Green 1994; =Syracosphaera noroiticus Knappertsbusch 1993, p. 71, 72, pl. 1, figs. 1-3; = Syracosphaera sp. type E Kleijne 1993) 
Genus A sp. type G (Kleijne) Aubry n.c. (= Syracosphaera sp. type G Kleijne 1993, p. 243, pl. 6, figs. 6, 9)

Genus A dilatata (Jordan, Kleijne and Heimdal, 1993) Aubry n.c. (=Syracosphaera dilatata Jordan, Kleijne and Heimdal, 1993, p. 20; = Caneosphaera halldalii f. dilatata Heimdal in Heimdal and Gaarder 1981, inv.)

Genus A sp. cf. Genus 1 dilatata (= Syracosphaera cf. S. dilatata Jordan, Kleijne and Heimdal, 1993 in Cros and Fortuño 2002

Genus A sp. type D (Kleijne) Aubry n.c. (= Syracosphaera sp. type D Kleijne 1993, p. 242, pl. 6, figs. 7,8$)$

Genus A pirus (Halldal and Markali) Aubry n.c. (= Syracosphaera pirus Halldal and Markali 1955, p. 11, pl. 10, figs. 1-4)

Genus A prolongata (Gran ex Lohmann) Aubry n.c. (= Syracosphaera prolongata Gran ex Lohmann 1913, p. 161, Fig. 16d, e)

Genus A prolongata (Gran ex Lohmann) Aubry n.c (= Syracosphaera prolongata Gran ex Lohmann 1913 sensu Heimdal and Gaarder 1981)

Genus A prolongata (Gran ex Lohmann) Aubry n.c. (= Syracosphaera prolongata Gran ex Lohmann 1913 sensu Throndsen 1972)

Syracosphaera Lohmann 1902 emended Gaarder 1977

Syracosphaera pulchra Lohmann 1902

Syracosphaera histrica Kamptner 1941

Family Umbellosphaeraceae Young and Kleijne in Young et al., 2003

Umbellosphaera Paasche in Markali and Paasche 1955

Umbellosphaera irregularis Paasche in Markali and Paasche 1955

Umbellosphaera tenuis (Kamptner) emended Paasche in Markali and Paasche 1955 (= Coccolithus tenuis Kamptner 1937)

Umbellosphaera tenuis (Kamptner) Paasche Type II Kleijne 93

Umbellosphaera tenuis (Kamptner) Paasche Type III Kleijne 93

Umbellosphaera tenuis (Kamptner) Paasche Type IV Kleijne 93 


\section{$\underline{\text { Fossil taxa }}$}

Discolithus ribosus Kamptner 1967

Syracosphaera clathrata Roth and Hay in Hay, Mohler, Roth, Schmidt, and Boudreaux, 1967

Syracosphaera clava Hay and Beaudry 1973

Syracosphaera decussata Hay and Beaudry 1973

Syracosphaera lamina de Kaenel and Villa 1996

Syracosphaera sp. cf. S. pirus Stradner and Fuchs 1978

Syracosphaera sp. Cohen and Reinhardt, 1968 (= Discolithus histricus (Kamptner) Cohen 1964)

Syracosphaera sp. Hay and Beaudry 1973

Syracosphaera sp. Müller 1974

Syracosphaera sp. 1 Okada 1990

Syracosphaera? fragilis Theodoridis 1984

? Syracosphaera lunularia Stradner and Fuchs 1978

?Syracosphaera tanzanensis Bown 2005

Syracosphaera sp. in Bown et al. (2008)

*Monothecatism characterizes the genus Caneosphaera. There is a difficulty with this however, since the exococcosphere may not always be present in otherwise dithecate species. Young et al. (2003) remarked that no exococcosphere is known in the common (generotype) C. halldalii. The species protrudens and epigrosa are not as well known, and it is possible that an exococcophere will be found. Their assigment to Caneosphaera is provisional. 
Appendix 3. Taxonomic revision of caneolith-bearing taxa.

Order Syracosphaerales Hay 1977 emended Young et al., 2003

\section{1- Family Deutschlandiaceae Kamptner 1928 emend.}

Generotype: Deutschlandia Lohmann 1912 emend. Gaarder 1981, emended herein

Emended definition. Cells are biflagellate. Coccosphere dithecate during the diploid stage of life cycle. Endotheca dimorphic (more?) consisting exclusively of caneoliths. Exotheca consisting exclusively of (sometimes strongly derived) cyrtoliths. Exotheca may be continuous over the whole endotheca, or restricted to only part of it. Dithecatism is thus complete, hemispherical, circum or polar. In the cases of polar dithecatism, cyrtoliths are arranged in a rosace, and some may also be aligned in rows and form long appendages. Coccosphere during haploid stage (known as yet only in Deutschlandia) monothecate, consisting of holococcoliths. Remarks. Differs from the Family Syracosphaeraceae by possessing cyrtoliths. Cyrtoliths are coccoliths characteristically built of three cycles of elements lying in almost the same horizontal plane, the elements of the intermediate cycle typically alternating with those of the outer cycle. Basic morphology is circular, the width of the outer and intermediate cycles varying greatly. This produces a large array of forms. Derived morphologies are elliptical, contorted, and in extreme cases, discoidal-truncated-, link-, and spine-cyrtoliths.

Generic content: Calciopappus, Deutschlandia, Michaelsarsia, Ophiaster.

Genus Deutschlandia Lohmann 1912 emend. Gaarder 1981, emend.

Type species: Deutschlandia anthos Lohmann 1912

Emended definition: Exotheca may be complete, hemisphaerical, circum or polar. When dithecatism is polar, imbricated derived exococcoliths form a simple, articulated rosace.

Genus Calciopappus Gaarder and Ramsfjell emended Manton and Oates 1983

Type species: Calciopappus caudatus Gaarder and Ramsfjell 1954 
Remarks: Highly derived cyrtoliths involved in polar dithecatism. Apical apparatus consists of articulated discoidal-truncated and spine-cyrtoliths forming a double corolla.

\section{Genus Ophiaster emended Manton and Oates 1983}

Type species: Ophiaster formosus Gran 1912 sensu Gaarder 1967 emended Manton and Oates 1983

Remarks: Highly derived cyrtoliths involved in polar dithecatism. Antapical apparatus consisting of link-cyrtoliths homologous to the spine-cyrtoliths of Calciopappus and forming a pseudocorolla. Differentiated antapical caneoliths where appartus is located. Caneoliths otherwise as in Calciopappus. This plus similar organic scales imply close phylognetic relationship.

\section{Genus Michaelsarsia Gran 1912 emended Manton, Bremer and Oates 1984}

Type species: Michaelsarsia elegans Gran in Murray and Hjort 1912 emended Manton, Bremer and Oates, 1984

Remarks: Highly derived cyrtoliths involved in polar dithecatism. Apical apparatus consists of articulated discoidal-truncated to which are fastened articulated link-cyrtoliths, forming a compound corolla. Polar apparatus convergent with those of Calciopappus and Ophiaster.

\section{2- Family Syracosphaeraceae (Lohmann 1902) Lemerman 1903 emend.}

Generotype: Syracosphaera Lohmann 1902 emend. Gaarder in Gaarder and Heimdal 1977.

Emended definition: Cells are biflagellate with a well differentiated flagellar opening. Coccosphere monothecate, dithecate or spirothecate during the diploid stage of the life cycle. Endotheca dimorphic, consisting exclusively of caneoliths. Exotheca consisting of modified caneoliths. Coccosphere monothecate during haploid stage, consisting of holococcoliths. 
Remarks. The family is emended here to exclude cyrtolith-bearing species, which form a natural, highly differentiated group (Family Deutchlandiaceae).

Generic content: Calciopappus, Deutschlandia, Michaelsarsia, Ophiaster.

Genus Caneosphaera Gaarder in Gaarder and Heimdal 1977 ex Jordan and Green 1994

Type species: Caneosphaera halldalii (Gaarder) Gaarder in Gaarder and Heimdal 1977

Remarks. Monothecatism during diploid stage is the distinctive character. Because in some species the exotheca is rarely found, some taxa are only provisionally assigned to this genus.

The genus Caneosphaera was invalidly introduced by Gaarder ( in Gaarder and Heimdal, 1977) because it was based on the invalidly described species Syracosphaera halldali Gaarder (in Gaarder and Hasle, 1977, p. 536). The name halldali was assigned to a taxon erroneously referred to as Syracosphaera mediterranea Lohmann by Halldal and Markali (1954). Whereas a full description of this taxon using electron microscopy was given by Halldal and Markali (1954), Gaarder omitted to provide a latin description of it. Syracosphaera halldali was validated by Jordan and Green (1994, p. 160) who commented "Since S. halldali was invalidly published in Gaarder and Hasle (1971), the validity of subsequent related names has been brought into question. The genus Caneosphaera, created in the review of the Syracosphaera complex by Gaarder and Heimdal (1977), is invalid as they named S. halldalii as the type species". The validation of S. halldalii by Jordan and Green (1994) validated the genus Caneosphaera.

\section{Genus: Coronosphaera Gaarder in Gaarder and Heimdal 1977}

Type-species: Coronosphaera mediterranea (Lohmann) Gaarder in Gaarder and Heimdal 1977

Remarks: Monothecatism during the diploid stage is the distinctive character. The Coronosphaera-caneoliths differ from the Caneosphaera-caneoliths in possessing an inner marginal cycle of imbricate elements. This genus was excluded from the Family Syracosphaeraceae in Young et al. (2003) because of the imbricate inner (not outer as mistakenly reported) layer and the occurrence of 2 laths per rim. This layer probably results from the 
development of the low inner cycle that occurs in several species of the Family Syracosphaeraceae.

\section{Genus A.}

Remarks: This genus is informally introduced here for the species shown by Cros (2000) to possess and exotheca of little modified caneoliths.

\section{Genus Gaarderia Kleijne 1993}

Type species: Gaarderia corolla (Lecal) Kleijne 1993

Remarks: The coccosphere is spirothecate, with the inner coccoliths being caneoliths that progressively transform into umbroliths outwards. Kleijne (1993) refers to the large outer coccoliths as umbelloliths. However, structurally they are caneoliths but with reversed proportions between margin and central area.

\section{Genus Syracosphaera Lohmann 1902 emended Gaarder 1977}

Type-species: Syracosphaera pulchra Lohmann 1902

Remarks: The genus is used here sensu stricto for species whose exococcoliths are "distally convex with central depression" (Gaarder in Gaarder and Heimdal, 1977, p. 54).

\section{3- Family Umbellosphaeraceae Young and Kleijne 2003.}

Generotype: Umbellosphaera Paasche in Markali and Paasche 1955

Remarks. The taxonomic position of this family was regarded as uncertain by Young and Kleijne (2003). The unusual structure of the coccosphere (spirothecate) and of the marginal cycle (with broader polar elements) of umbelloliths are characters shared with Gaarderia. On this basis the two genera are regarded phylogenetically related, and Umbellosphaera is assigned to the Order Syracosphaerales.

\section{Genus Umbellosphaera Paasche in Markali and Paasche 1955}


Type-species: Umbellosphaera tenuis (Kamptner) Paasche in Markali and Paasche 1955

Remarks: Coccosphere is spirothecate. The innermost coccoliths (cannaliths) are very similar to caneoliths. 